
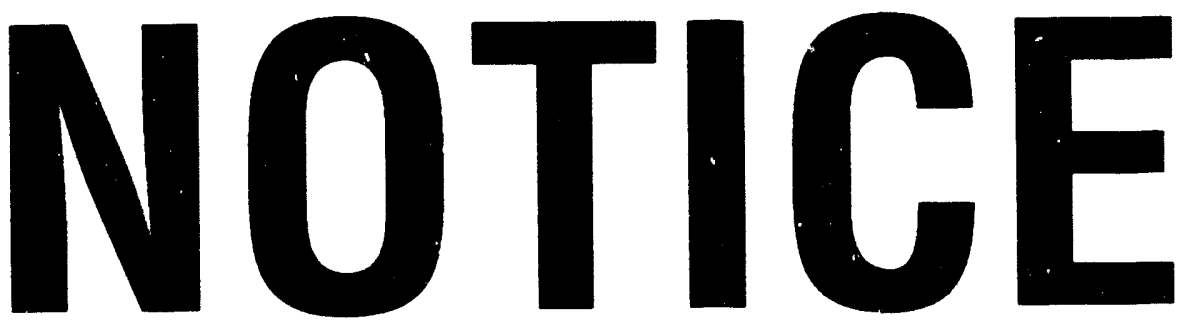

CERTAIN DATA
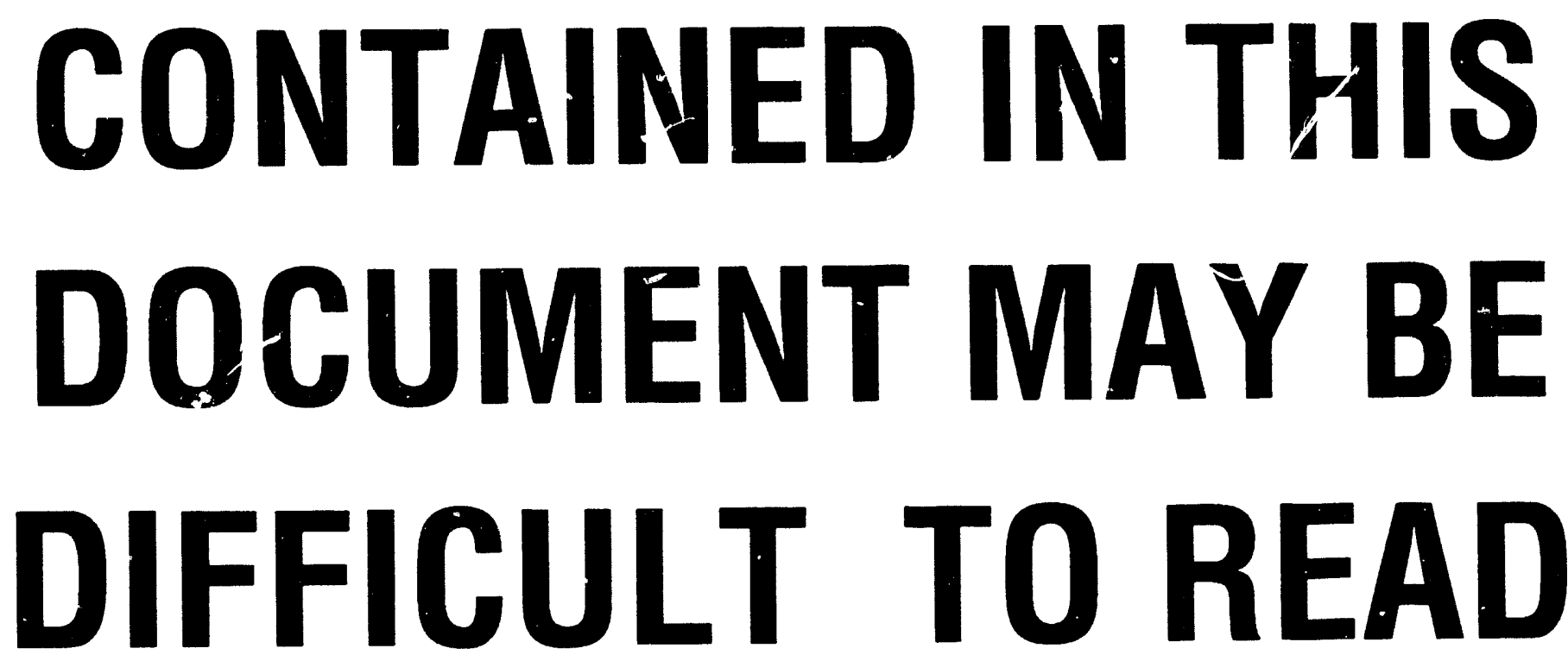

IN MICROFICHE

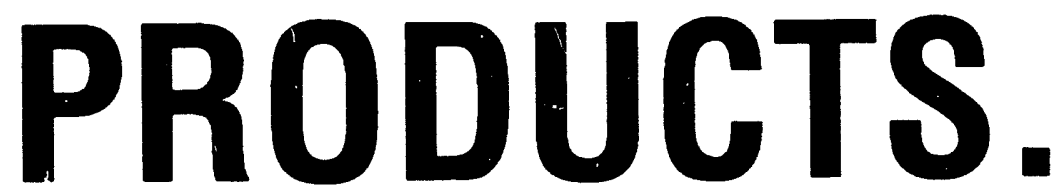




\section{Tank 241-A-105 Evaporation Estimate 1970 through 1978}

Prepared for the U.S. Department of Energy Assistant Secretary for Defense Programs

\section{(ve) Westinghouse Harford Company Richland. Washington}

Hantord Operations and Engineering Contractor for the

U.S. Department of Energy under Contract DE-AC06-87RL10930 


\section{LEGAL DISCLAIMER}

This report was prepared as an account of work sponsored by an agency of the United States Government. Neither the United States Government nor any agency thereof, nor any of their employees, nor any of their contractors, subcontractors or their employees, makes any warranty, express or implied. or assumes any legal liability or responsibility for the accuracy, completeness, or any third party's use or the results of such use of any information, apparatus, product, or process disclosed, or represents that its use would not infringe privately owned rights. Reference herein to any specific commercial product, process, or service by irade name. trademark, manulacturer, or otherwise, does not necessarily constitute or imply its endorsement, recommendation, or favoring by the United Siates Government or any agency thereof or its contractors or subcontractors. The views and opinions of authors expressed herein do not necessarily state or refleci those of the United Siates Government or any agency thereof

This report has been reproduced from the best avallable copy Avallable in paper copy and microfiche.

Avalable to the US Department of Energy and its contractors from

Office of Scientific and Technical Information

P.O Box 62

Oak Ridge, TN 37831

(615) 576.840

Avaliable to the public from the U.S. Department of Commerce National Technical informalion Service

5285 Porl Royal Road

Springtielo VA 22161

(703) 487.4650

Pinted in the Unitod States of America 
WHC-EP- -0410

DE92 000230

\section{Tank 241-A-105 Evaporation Estimate 1970 through 1978}

G. K. Allen

Date Published

September 1991

Prepared for the U.S. Department of Energy Assistant Secretary for Defense Programs

(2) Westinghouse $\begin{aligned} & \text { P.O. Box } 1970 \\ & \text { Hanford Company Richland. Wash }\end{aligned}$

Hanford Operations and Engineering Contractor for the

U.S. Department of Energy under Contract DE-AC06-87RL10930

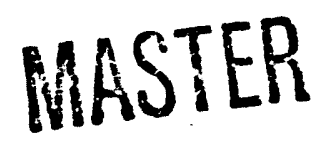

DISTRIBUTION OF THIS DOCUMENT IS UNLIMITED<smiles>[Te][Te]</smiles> 


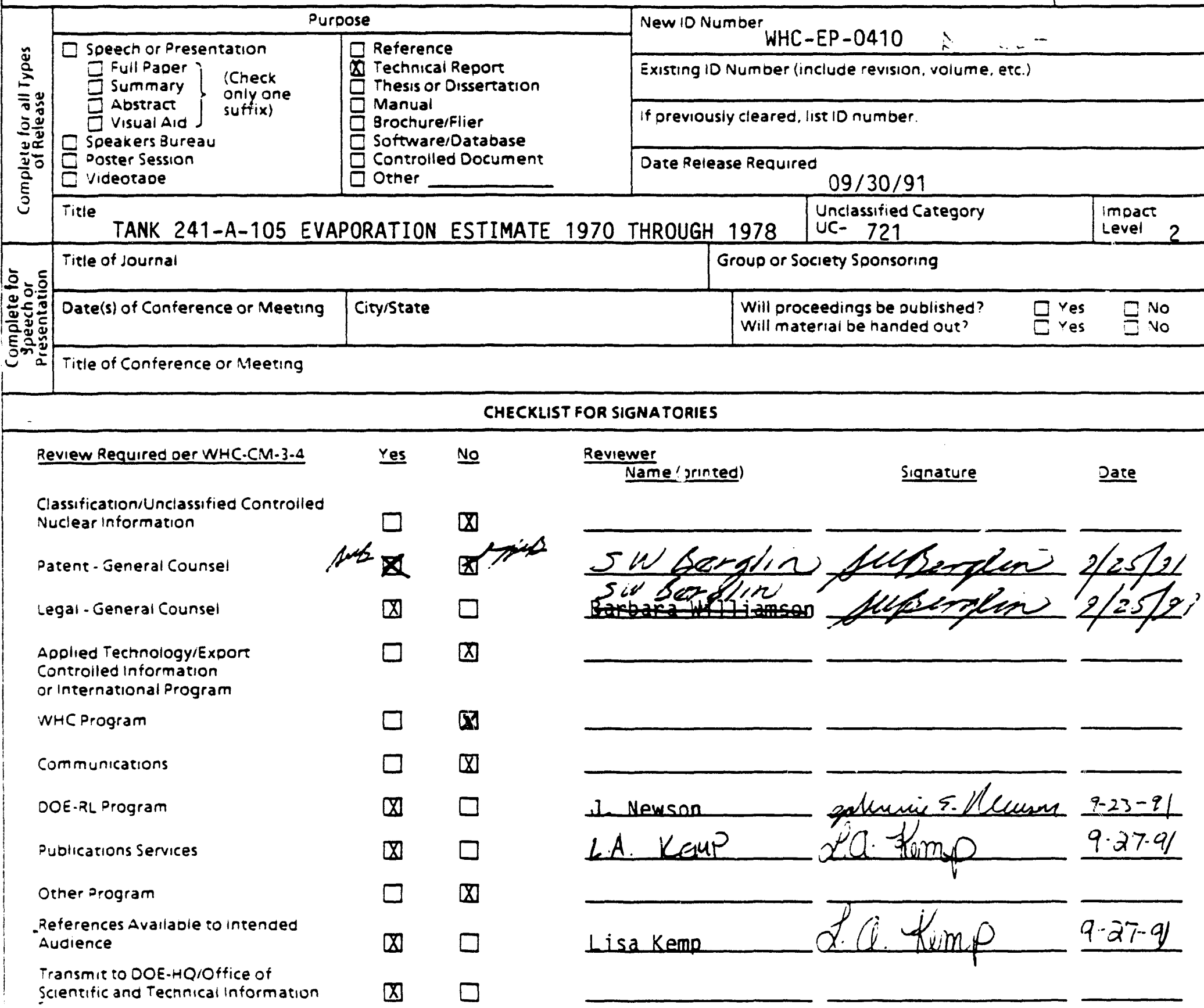

nformation conforms to all applicable requirements. The adove information is certified to de correct.

Author/Requestor (Printed/Signature)

G. K. Aflen

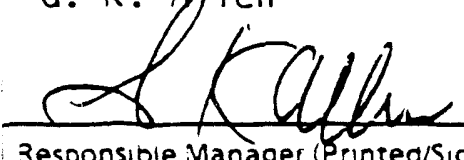

Responsible Manager (Printed/signature)

WALTER L. KNECHT

W. $2 \cdot$ Rnentht

ntenced dudience

$\square$ nternal $\square$ soonsor $\square$ External
Jate

\section{INFORMATION RELEASE ADMINISTRATION APPROVAL STAMP \\ Stamo is required deiore release Release is contingent udon resolution of} manaatory comments

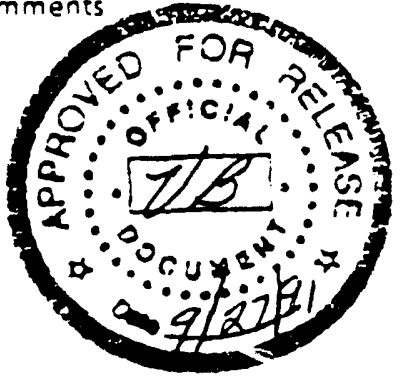

$9 / 12 / 91$

12 SETT 9)

$9 / 12 / 91$


Document Title: Tank 241-A-105 Evaporation Estimate 1970 Through 1978

Prepared by:

Reviewed by:

Approved by:

Approved by:

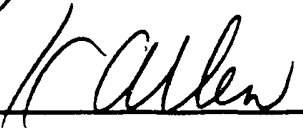

G. K. Allen

Waste Characterization Analys is

$\frac{\text { I. U. CCaybroole }}{\text { S. W. claybrook }}$ Numerical Applications, Inc.

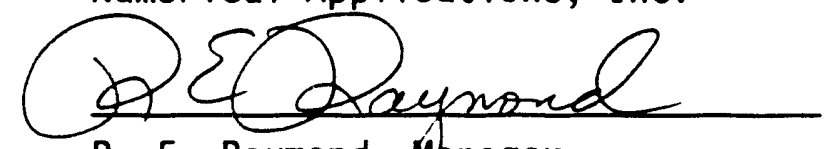

R. E. Raymond, Uanager

Single-Shell Tank Technology

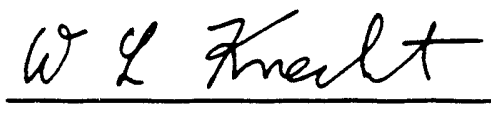

W. L. Knecht, Manager

Waste Characterization Analysis
27 Jun 91

Date

$\frac{11 \cos 91}{\text { Date }}$

$7-9-91$

Date

$9 / 11 / 91$

Date 
WHC-EP-0410

This page intentionally left blank. 
WHC-EP-0410

TANK 241-A-105 EVAPORATION ESTIMATE

1970 THROUGH 1978

\author{
G. K. Allen
}

\title{
ABSTRACT
}

Tank 241-A-105 was subjected to a severe steam explosion in January 1965 that caused the metal liner on the bottom to bulge upward approximately 8 feet above its concrete foundation. Shortly after this event, radiation was detected in drywells around the tank and it was declared a leaker. sluicing operations to remove material from the tank began in August 1968 and continued through August 1970. After sluicing was completed, a significant amount of heat generating material still remained in the tank. To keep tank temperatures below operating limits, the water level in the tank was maintained at an approximate depth of 1.5 feet. This practice was continued until January 1979 when it was believed that the contents had decayed sufficiently to discontinue the water addition and put the tank on a portable exhauster system.

Recent concern has focused on what portion of this cooling water added to Tank 241-A-105 actualiy evaporated and how much leaked into the soil during the nine year time period. This report presents the results of a study that estimates the amount of water evaporated from Tank 241-A-105 between 1970 and 1979. 
The problem was completed in two parts. The first part involved development of a three dimensional heat transfer model which was used to establish the tank heat load. The results of this model were validated against thermocouple data from Tank 241-A-105. The heat removed from the tank by the ventilation air was then used as input to a second computer code, which calculated the water evaporation. Based upon these two models, the amount of water evaporated from Tank 241-A-105, between 1970 and 1979, was between 378,000 and 410,000 gallons. 


\section{CONTENTS}

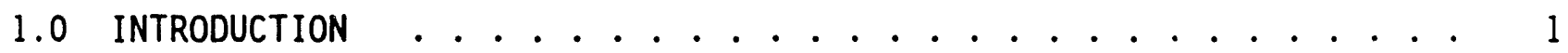

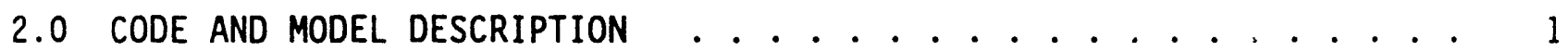

2.1 HEATING7 MODEL ASSUMPTIONS $\ldots \ldots \ldots$

2.2 FATHOMS MODEL ASSUMPTIONS ............... 11

2.2.1 Volume Assumptions ............. 11

2.2.2 Atmospheric Boundary Conditions .............. 11

2.2.3 Heat Boundary Conditions ............ 13

2.2.4 Additional Boundary Condition ........... 13

3.0 HEAT TRANSFER RESULTS . . . . . . . . . . . . . . . 13

4.0 EVAPORATION RESULTS . . . . . . . . . . . . . . . 24

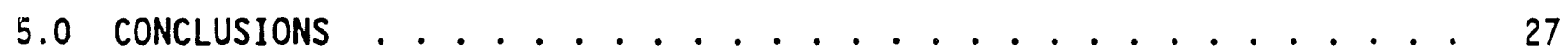

6.0 REFERENCES ...................... . . 28

\section{APPENDICES}

A HEAT TRANSFER STUDY ON TANK $241-A-105 \ldots \ldots$ APP $A-i$

B COMPOSITION AND DENSITY OF TANK 241-A-105 SOLIDS ...... APP B- $i$

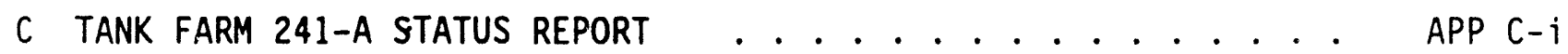

D RESULTS COMPARISON WITH DRAFT EBASCO ENVIRONMENTAL STUDY . . . APP D-i 


\section{WHC-EP-0410}

\section{FIGURES}

1 Side View, Tank 241-A-105 . . . . . . . . . . . . 3

2 Cylindrical Coordinate HEATING7 Model (radius-height orientation) 4

3 Tank Bottom Contour ................ 5

4 HEATING7 Model - Tank Bottom (radius-theta orientation) . . . . . 6

5 Tank Lateral Thermocouple Probes . . . . . . . . . . . . 9

6 FATHOMS Model .................. 12

7 Lateral Number 1 Temperature History . . . . . . . . . . . 15

8 Lateral Number 2 Temperature History . . . . . . . . . . 16

9 Lateral Number 3 Temperature History . . . . . . . . . . . . . . 17

10 Lateral Number 4 Temperature History . . . . . . . . . . . . 18

11 Calculated Teimperature Contour $2 \mathrm{ft}$ Below Tank Bottom, $1968 \ldots 19$

12 Calculated Temperature Contour $2 \mathrm{ft}$ Below Tank Bottom, 1978 . . . 20

13 Temperature Surface $2 \mathrm{ft}$ Below Tank Bottom, $1968 \ldots \ldots 21$

14 Temperature Surface $2 \mathrm{ft}$ Below Tank Bottom, $1978 \ldots 22$

15 Temperature $2 \mathrm{ft}$ Below Tank After Portable Exhauster Failure . . . 23

16150 CFM Air Flow Rate . . . . . . . . . . . . . 25

17660 CFM Air Flow Rate . . . . . . . . . . . . . . 26 
WHC-EP-0410

\section{TABLES}

1 Material Properties . . . . . . . . . . . . 7

2 Air Temperature Dependant Properties . . . . . . . . . 8

3 Assumed Model Heat Generation Rates ............... 10

4 Assumed Model Yearly Heat Generation Rates . . . . . . . . . . 10

5 Average Psychrometric Properties . . . . . . . . . . . . 11

6 Sludge Temperatures, Tank 241-A-105 $1.5 \mathrm{ft}$ from Tar.k Bottom . . . . 24

7 Water Evaporated from Tank 241-A-105 . . . . . . . . . 27 
WHC-EP-0410

This page intentionally left blank. 
WHC-EP-0410

\section{TANK 241-A-105 EVAPORATION ESTIMATE 1970 THROUGH 1978}

\subsection{INTRODUCTION}

Tank 241-A-105 was subjected to what was postulated as a severe steam explosion (Beard et al. 1967) in January 1965, which caused the metal liner on the bottom to bulge upward approximately $8 \mathrm{ft}$ above its concrete foundation. This bulge created tears in the metal liner around the perimeter of the tank where the bottom meets the side. Sluicing operations to remove as much material as possible from the tank began in August 1968 and continued through August 1970. At that time, there was still a considerable amount of heat generating material in or under the tank causing high tank temperatures. To maintain tank temperatures within operating 1 imits, the water level in the tank was maintained at an approximate depth of $1.5 \mathrm{ft}$. The liquid level was monitored and when it fell below this level, water was added to bring the level back to $1.5 \mathrm{ft}$ deep. This practice was continued until January 1979 when it was believed that the contents had decayed sufficiently to discontinue the water addition and put the tank on a portable exhauster system. A process test was conducted to test if this change of operation could be done without exceeding maximum tank temperature criteria (Carl 1978). The results of this test indicated that cooling water could be eliminated without exceeding maximum tank temperature limits. At this time water additions were discontinued and Tank 241-A-105 was placed on a portable exhauster.

Recent concern has focused on how much of the cooling water added to Tank 241-A-105 actually evaporated and how much leaked into the soil during the nine year time period it was added. This report presents the results of a study estimating the amount of water that evaporated from Tank 241-A-105 when waier was added for cooling purposes from 1970 through 1978.

\subsection{CODE AND MODEL DESCRIPTION}

Two computer codes were used in this study: HEATING7 and FATHOMS. The HEATING7 computer code is a multidimensional heat conduction code designed to solve steady-state and/or transient heat conduction problems (Childs 1991). The FATHOAS computer code is a multidimensional thermal hydraulics code that was originally designed to model multi-component, two-phase flows in nuclear reactor power plant containment and auxiliary buildings (Burke 1990). However, the FATHOMS computer code is applicable to a wide range of thermalhydrautic problems.

Calculation of the evaporation rate in Tank $241-A-105$ is broken into two parts. The first part involved using the HEATING7 computer code to estabiish the existing heat content of the tank. The HEATING7 model assumptions were adjusted until the model calculated the same conditions that were seen in thermocouples, located in laterals underneath the tank. Once the HEATING7 model matched the data, it was used to establish the amount of heat 
that was removed from the tank through the air ventilation system. This heat value was then used as input for the FATHOMS model. The FATHOMS code calculated the evaporation rates inside the tank based upon assumed exhauster flow rates.

\subsection{HEATING7 MODEL ASSUMPTIONS}

A three-dimensional HEATING7 model was used to represent Tank 241-A-105. The three dimensional model is necessary because the sludge in the bottom of the tank is not uniformly distributed, but located in several piles on the tank floor. In addition, the tank bottom is bulged, which will affect how much of the tank floor is actually covered with cooling water.

A side view of the tank is shown in Figure 1. Tank dimensions shown were taken from Drawing $\mathrm{H}-2-55911$ (WHC 1991). A HEATING7 model using cylindrical coordinates was used to model the tank. Results of converting the tank in Figure 1 to cylindrical coordinates are shown in Figure 2, which shows a radius-height ( $r z$ ) view of Figure 1. A contour plot of the tank bottom, shown in Figure 3 (Carl 1978), gives the location of the sludge piles as well as the bulged liner. The sludge piles in Figure 3 are modeled as shown in Figure 4. This is a radius-theta $(r \theta)$ representation of the sludge contours shown in Figure 3. The slashed areas represent sludge piles, diamond hashed areas show water, and clear areas show the bulged tank bottom which sticks above the $1.5 \mathrm{ft}$ of cooling water in the tank. The volume of sludge is estimated to be $2,365 \mathrm{cu} f t$ (Appendix A). Using this volume and the tank bottom surface area covered with sludge, shown in Figure 4 , gives an average sludge height of $1.357 \mathrm{ft}$.

The location of the boundary conditions are shown in Figure 2. Boundary condition (bc) 1 is a forced convective boundary condition with a forced convective heat transfer coefficient of $2 \mathrm{Btu} /\left(\mathrm{h} \cdot \mathrm{ft}^{2} \cdot{ }^{\circ} \mathrm{F}\right)$ convecting to a $55^{\circ} \mathrm{F}$ temperature. This bc approximates an average wind speed across the soil surface convecting to the yearly average air temperature. Boundary condition 2 is an adiabatic boundary that approximates a tank center-to-center spacing of $102 \mathrm{ft}$. By using this bc, the model is assuming an infinite array of tanks, which have a 102-ft center-to-center spacinc. Boundary condition 3 is an isothermal bc of $55^{\circ} \mathrm{F}$ located at the water table. Boundary condition 4 is an isothermal surface-to-boundary condition with the boundary temperature set to $130^{\circ} \mathrm{F}$. This bc was established by review of in tank temperature records taken in the 1968 through 1978 time period. Sludge temperatures during this period ranged from $115^{\circ} \mathrm{F}$ to $130^{\circ} \mathrm{F}$, with more measurements in the $130^{\circ} \mathrm{F}$ range than the $115^{\circ} \mathrm{F}$ range. Boundary condition 5 is a surface-tosurface bc that models the radiation heat transfer between the tank bottom and dome and the natural convection inside the tank. The radiative heat transfer coefficient is $1.2 \times 10^{-9} \mathrm{Btu} /\left(\mathrm{h} \cdot \mathrm{ft}^{2} \cdot{ }^{\circ} \mathrm{R}^{4}\right)$. This value was derived from Equation 1.

$$
h_{I}=S \times s b
$$


WHC-EP-0410

Figure 1. Side View, Tank 241-A-105.

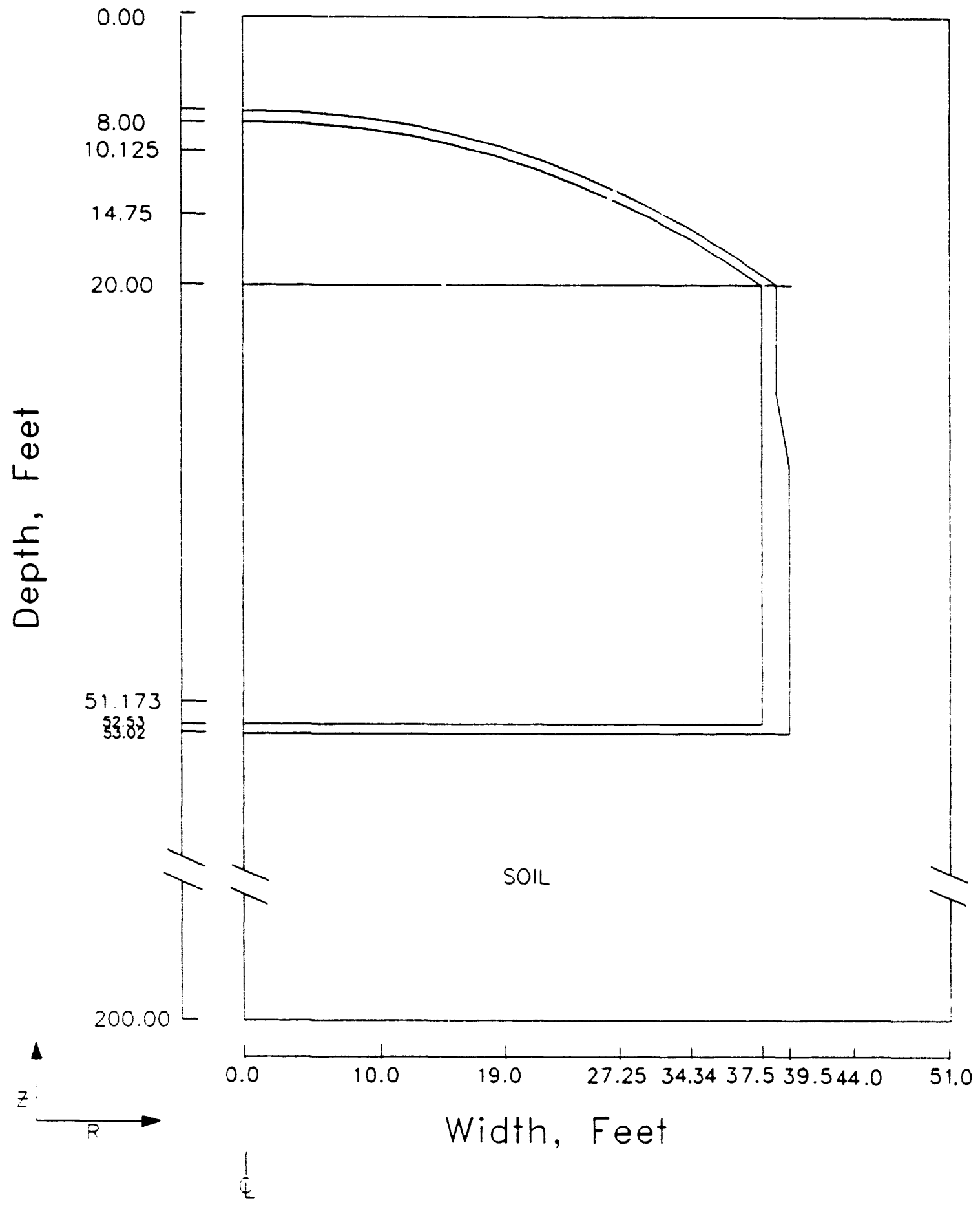


WHC-EP-0410

Figure 2. Cylindrical Coordinate HEATING7 Model (radius-height orientation).

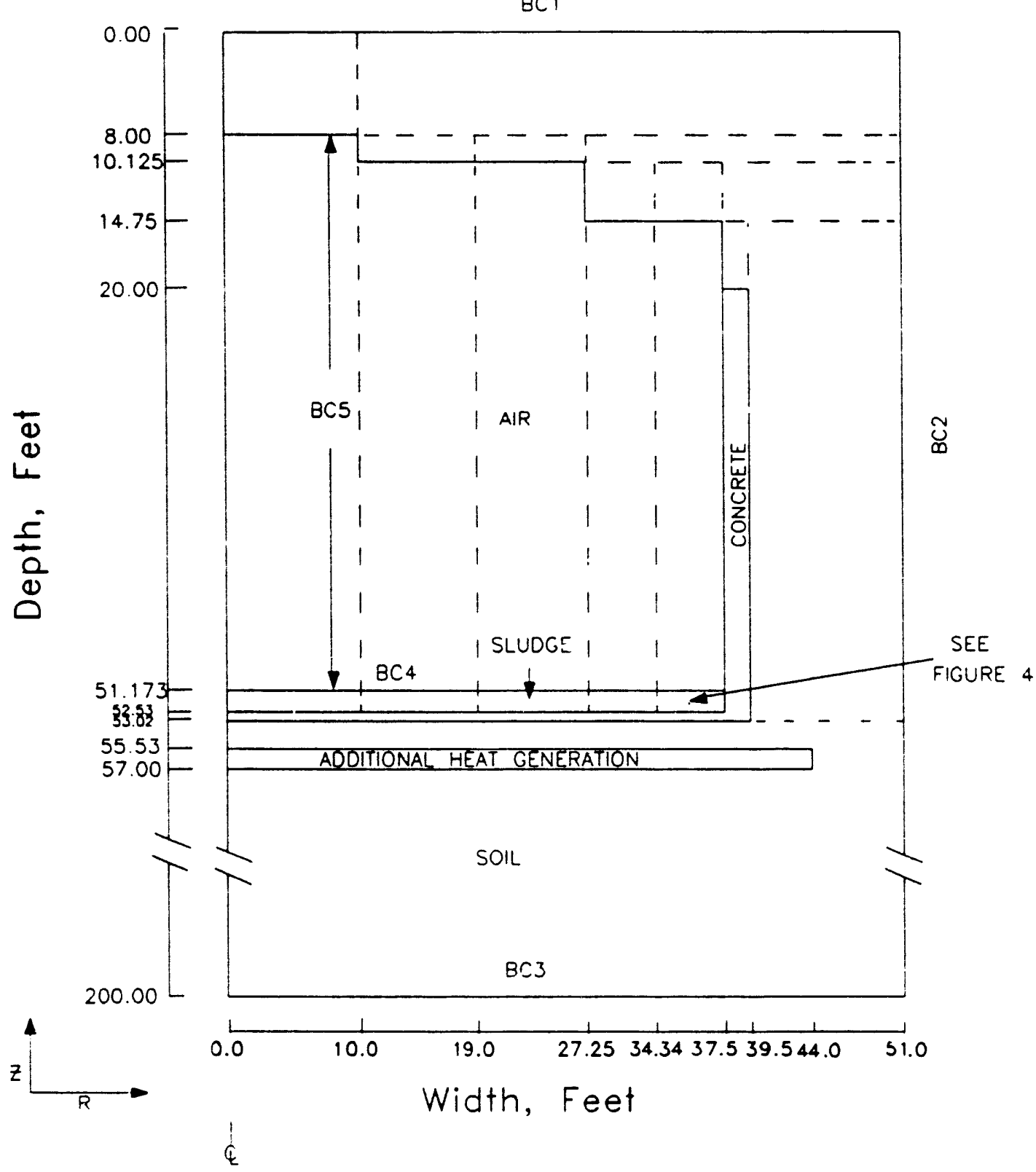


$W H C-E P-0410$

Figure 3. Tank Bottom Contour.

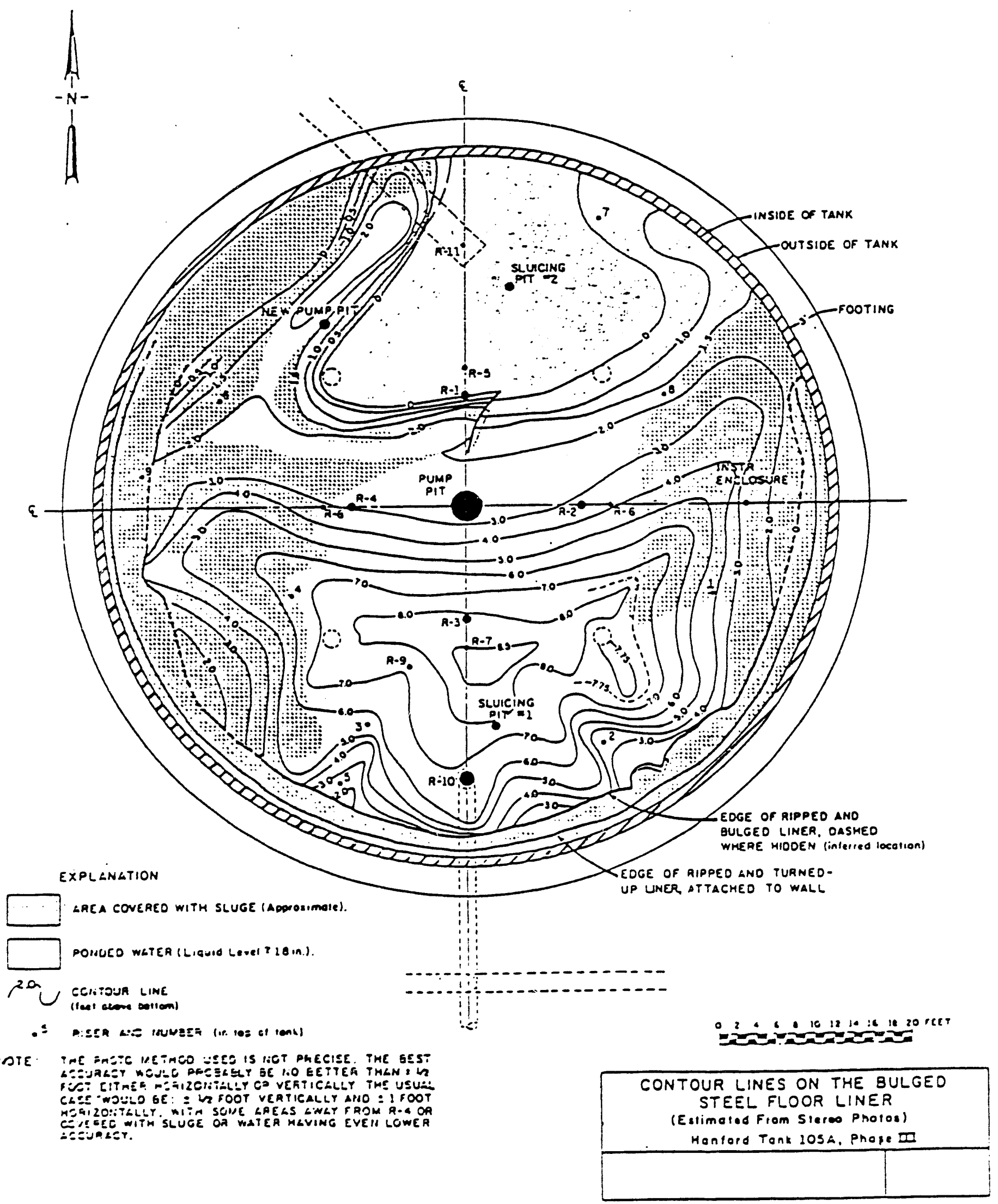


WHC-EP-0410

Figure 4. HEATING7 Model - Tank Bottom

(radius-theta orientation).

\section{1}

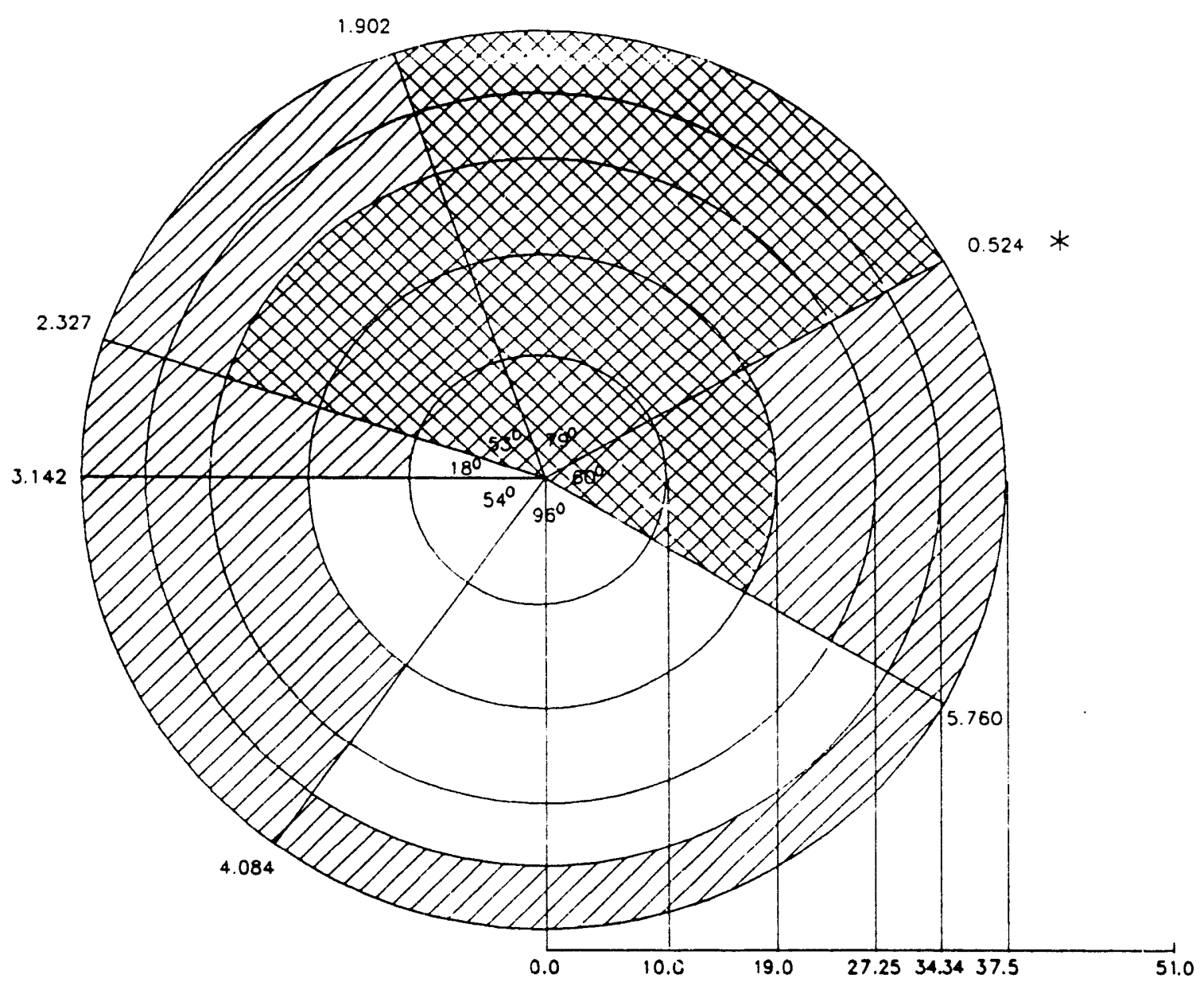

* UNITS $=$ RADIANS

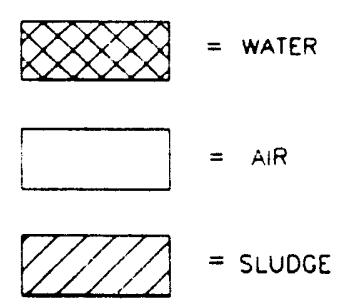


where

$S=$ shape factor assumed to be 0.7

$s b=$ Stefan-Boltzman constant which is $1.714 \mathrm{e} \times 10^{-9} \mathrm{Btu} /\left(\mathrm{h} \cdot \mathrm{ft}^{2} \cdot{ }^{\circ} \mathrm{R}^{4}\right)$.

The natural convective heat transfer coefficient is $0.11 \Delta t^{0.25}$. This heat transfer coefficient is based upon the general correlation shown in Equation 2.

$$
\mathrm{h}=\mathrm{C} \times\left[\frac{\Delta \mathrm{T}}{\mathrm{L}}\right]^{\mathrm{n}}
$$

where

$$
\begin{aligned}
& C=0.27 \\
& L=\text { characteristic length } 37.5 \\
& n=0.25 .
\end{aligned}
$$

These values are based upon a horizontal plate with the heated surface facing up (Welty et al. 1969).

\begin{tabular}{|c|c|c|c|}
\hline Material & $\begin{array}{c}\text { Thermal conductivity } \\
\mathrm{Btu} / \mathrm{h} \cdot \mathrm{ft} \cdot{ }^{\circ} \mathrm{F}\end{array}$ & Density $1 \mathrm{~b} / \mathrm{ft}^{3}$ & $\begin{array}{c}\text { Specific heat } \\
\left.\text { Btu/(1b. }{ }^{\circ} \mathrm{F}\right)\end{array}$ \\
\hline Sludge & 100.0 & 500.0 & 0.1 \\
\hline Soil & 0.3 & 111.1 & 0.2 \\
\hline Concrete & 0.7 & 144.0 & 0.21 \\
\hline Air & \multicolumn{3}{|c|}{ Temperature dependant properties, see Table 2} \\
\hline Water & 0.364 & 62.1 & 0.999 \\
\hline
\end{tabular}

Five materials are used in this model whose thermal properties are shown in Table 1.

Table 1. Material Properties.

The thermal properties of the sludge are artificially high to allow the heat to flow freely to the heat generation boundary. This assumption is used to simplify the computer code computations. The major resistance to heat transfer is the air inside the tank, so this simplifying assumption will have no impact on the overall heat transfer problem. In addition, the sludge temperatures were of no interest to this study. The temperature dependant air properties assumed are listed in Table 2. 
Table 2. Air Temperature Dependant Properties.

\begin{tabular}{|c|c|c|c|}
\hline Temperature & $\begin{array}{c}\text { Thermal conductivity } \\
\left.\text { Btu/(h. ft. }{ }^{\circ} \mathrm{F}\right)\end{array}$ & $\begin{array}{c}\text { Density } \\
1 \mathrm{~b} / \mathrm{ft}^{3}\end{array}$ & $\begin{array}{c}\text { Specific heat } \\
\mathrm{Btu} /\left(1 \mathrm{~b} \cdot{ }^{\circ} \mathrm{F}\right)\end{array}$ \\
\hline 60 & 0.0146 & 0.0764 & 0.240 \\
\hline 80 & 0.0152 & 0.0735 & 0.240 \\
\hline 100 & 0.0156 & 0.0710 & 0.240 \\
\hline 150 & 0.0167 & 0.0651 & 0.241 \\
\hline 200 & 0.0179 & 0.0602 & 0.241 \\
\hline 250 & 0.0191 & 0.0559 & 0.242 \\
\hline
\end{tabular}

Four lateral thermocouple probes, which measures soil temperature, are located $2 \mathrm{ft}$ underneath the bottom of Tank 241-A-105, as shown in Figure 5 . The tank heat generation rate was derived by adjusting its value so the calculated model temperatures matched the measured thermocouple readings of the soil temperatures in the laterals underneath the tank. Initially, all the heat was placed in the sludge inside the tank, but temperatures $2 \mathrm{ft}$ underneath the tank were not high enough to match measured values from thermocouples inside the laterals. The only way the model would match measured lateral temperatures was to place a second smaller heat generation region underneath the tank. Lateral temperature data are available from 1968 to 1978. Two steady state runs were completed: one matched the 1968 lateral temperature measurements and a second matched the 1978 lateral temperature measurements. The heat generation rates for the two cases are shown in Table 3.

The major radionuclide in the sludge is strontium-90 (Appendix B) which has a half life of 28.6 years. Based upon this half life, the radioactive decay for the heat generation is shown in Equation 3.

$$
q=q_{0} e^{-0.024236 \times t}
$$

where

$q_{0}=$ initial heat generation rate

$t=$ time in years.

The in-tank heat generation rate, assumed in Table 3 , used this decay to decrease its heat generation between 1968 and 1978. Initially, this same assumption was used for the heat generation underneath the tank, but when a suitable heat generation rate for the 1968 time period was found and decayed to its 1978 value, temperatures were too high. Only when the heat generation rate underneath the tank was reduced, to that shown in Table 3 , did the temperatures match. The yearly tank heat generation rates between 1968 and 1978 can now be calculated and are shown in Table 4. 
WHC-EP-0410

Figure 5. Tank Lateral Thermocouple Probes.

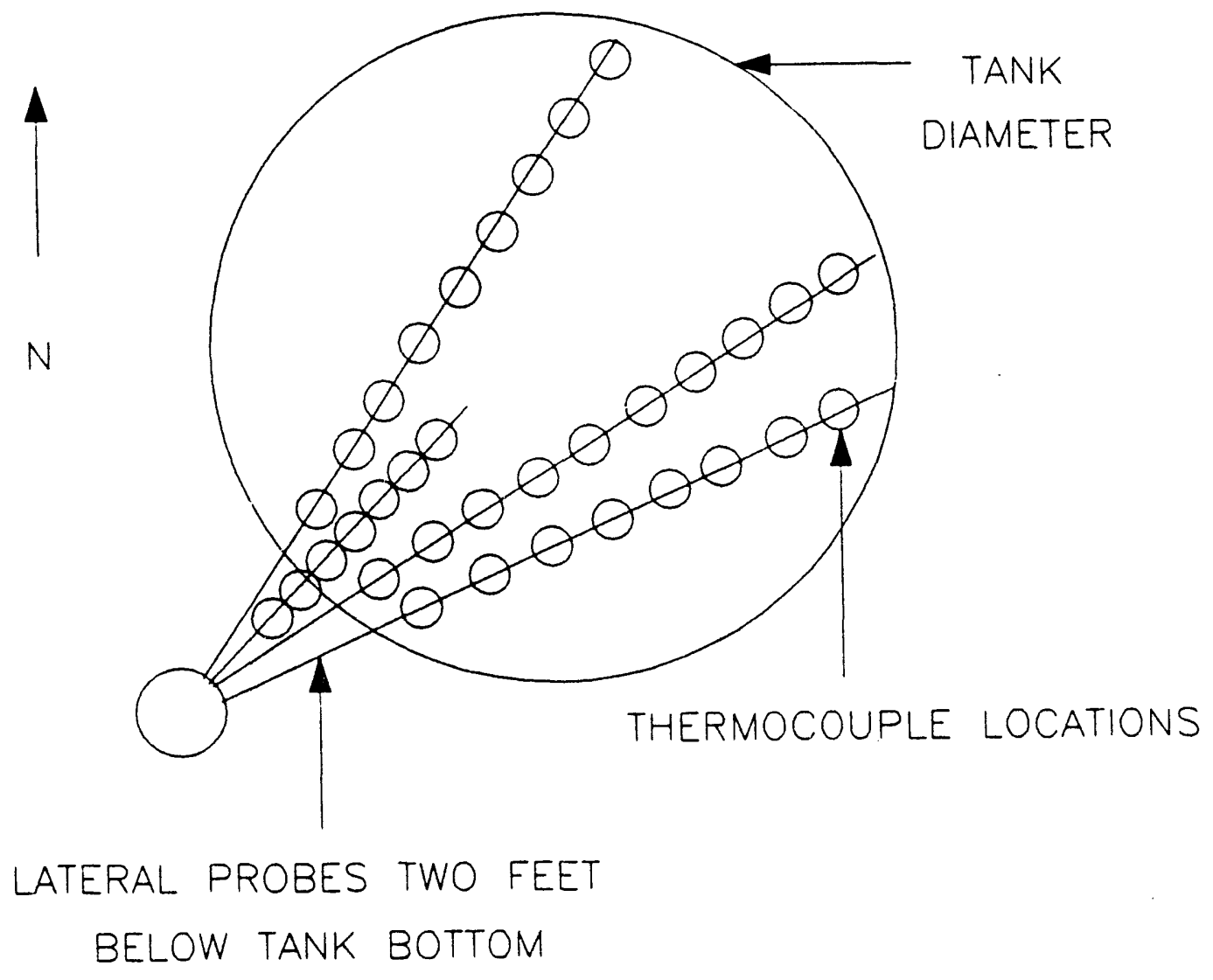


Table 3. Assumed Model Heat Generation Rates.

\begin{tabular}{|c|c|c|c|c|}
\hline \multirow[t]{2}{*}{ Year } & \multicolumn{2}{|c|}{$\begin{array}{c}\text { Volumetric heat generation } \\
\text { rate } \mathrm{Btu} /\left(\mathrm{h} \cdot \mathrm{ft}^{3}\right)\end{array}$} & \multicolumn{2}{|c|}{$\begin{array}{c}\text { Total heat generation rate } \\
\text { Btu } /\left(h \cdot \mathrm{ft}^{3}\right)\end{array}$} \\
\hline & In tank & Under tank & In tank & Under tank \\
\hline 1968 & 24.21 & 3.4 & $57,192.5$ & $30,383.0$ \\
\hline 1978 & 19.0 & 1.6 & $44,884.6$ & $14,297.9$ \\
\hline
\end{tabular}

Table 4. Assumed Model Yearly Heat Generation Rates.

\begin{tabular}{|c|c|c|c|}
\hline \multirow{2}{*}{ Year } & \multicolumn{2}{|c|}{$\begin{array}{c}\text { Volumetric heat generation rate } \\
\text { Btu/ }\left(\mathrm{h} \cdot \mathrm{ft}^{3}\right)\end{array}$} & $\begin{array}{c}\text { Heat removed from } \\
\text { tank vapor space Btu/h }\end{array}$ \\
\cline { 2 - 4 } & In tank & Under tank & $71,395.6$ \\
\hline 1968 & 24.21 & 3.4 & $68,330.9$ \\
\hline 1969 & 23.63 & 3.2 & $65,334.0$ \\
\hline 1970 & 23.064 & 3.004 & $62,421.1$ \\
\hline 1971 & 22.512 & 2.814 & $59,563.9$ \\
\hline 1972 & 21.973 & 2.627 & $56,788.5$ \\
\hline 1973 & 21.447 & 2.446 & $54,067.2$ \\
\hline 1974 & 20.933 & 2.268 & $51,418.3$ \\
\hline 1975 & 20.432 & 2.095 & $48,831.9$ \\
\hline 1976 & 19.943 & 1.926 & $46,307.2$ \\
\hline 1977 & 19.465 & 1.971 & $43,844.4$ \\
\hline 1978 & 19.0 & 1.6 & \\
\hline
\end{tabular}

The in-tank heat generation rate in Table 4 was calculated based solely on Equation 3. The under tank heat had to be decreased faster than predicted by Equation 3 alone and an additional factor was used to decrease this rate. It is postulated that this additional factor required for the under tank heat generation rate is necessary because the leak plume is being washed deeper into the soil column by the cooling water leaking from the tank. These values were then input into a HEATING7 model that calculated the heat removed from the tank vapor space. This heat generation is used as input to the FATHOMS model, which is discussed in the following section.

After 1978, when the cooling water was discontinued, the heat generation rate for transient analyses used the decay functions of Equation 3 for both the in tank and under tank heat generation rate. This indicates that after the cooling water was discontinued, the heat generation underneath the tank remained stationary. 


\subsection{FATHOMS MODEL ASSUMPTIONS}

The FATHOMS model is shown in Figure 6 . The model consists of a tank containing a layer of water in the bottom. Air is pumped into the tank from the upper right side of the model and exits out the top left side. Heat is by the incoming air. Model assumptions are broken into atmospheric boundary conditions, heat boundary conditions, and model volume assumptions as discussed in the following paragraphs.

\subsubsection{Volume Assumptions}

The tank voluine assumed for the FATHOMS model was $172,369 \mathrm{ft}^{3}$. This value was calculated based upor the air volume above the sludge using the HEATING7 model configuration. The surface area for water evaporation was $4,417 \mathrm{ft}^{2}$, which was based upon the surface area of the tank.

\subsubsection{Atmospheric Boundary Conditions}

The air being pumped through the tank is assumed to be at seasonal ambient air conditions. The seasonal conditions used are shown in Table 5 which gives a monthly average between the years 1950 and 1970 [taken from Table 2.3-8 of WHC-EP-0240-1 (WHC 1978)].

Table 5. Average Psychrometric Properties.

\begin{tabular}{|c|c|c|c|c|}
\hline Month & $\begin{array}{c}\text { Dry bulb } \\
\text { temperature, }{ }^{\circ} \mathrm{F}\end{array}$ & $\begin{array}{c}\text { Relative } \\
\text { humidity }\end{array}$ & $\begin{array}{c}\text { Saturated vapor } \\
\text { pressure (fsia) }\end{array}$ & $\begin{array}{c}\text { Pressure } \\
\text { ratio }\end{array}$ \\
\hline Jan & 30.3 & 76.0 & 0.0 & 0.0 \\
\hline Feb & 37.5 & 69.7 & 0.1101 & 0.005348 \\
\hline Mar & 44.0 & 55.0 & 0.1419 & 0.005439 \\
\hline Apr & 52.5 & 46.4 & 0.1955 & 0.006322 \\
\hline May & 61.8 & 41.8 & 0.2736 & 0.007974 \\
\hline Jun & 69.9 & 39.4 & 0.3628 & 0.009963 \\
\hline Jul & 77.5 & 31.5 & 0.4683 & 0.010281 \\
\hline Aug & 75.3 & 34.9 & 0.4353 & 0.010588 \\
\hline Sep & 67.0 & 39.9 & 0.3283 & 0.009130 \\
\hline Oct & 53.2 & 57.7 & 0.2006 & 0.008067 \\
\hline Nov & 40.1 & 72.6 & 0.1220 & 0.006173 \\
\hline Dec & 33.4 & 80.8 & 0.0935 & 0.005265 \\
\hline
\end{tabular}

psia = pounds per square-inch absolute (pressure). 
WHC-EP-0410

Figure 6. FATHOMS Model.

OUTLET

AIR

FLOW

TANK VOLUME .

INLET

AIR

FLOW

COOLING WATER VOLUME

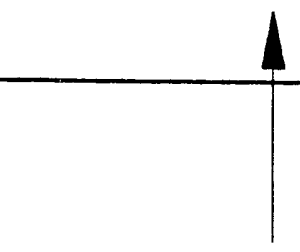

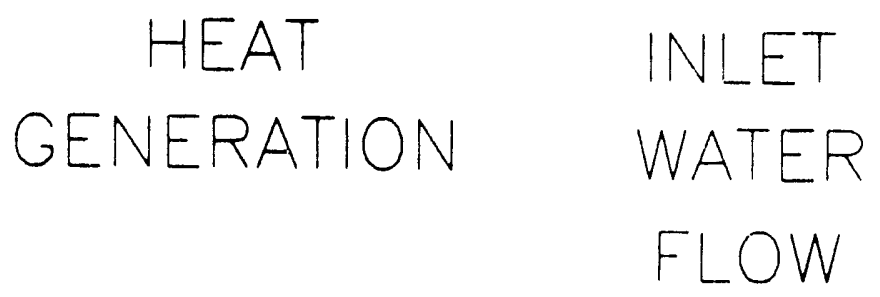


The FATHOMS computer code uses a pressure ratio rather than relative humidity directly. The pressure ratio is defined by Equation 4.

$$
\text { pressure ratio }=\text { relative humidity } \times \frac{\mathrm{P}_{\text {sat }}}{\mathrm{P}_{\text {tot }}} .
$$

The total pressure is 14.348 psia (Garfield 1975). In addition, the initial temperature of the vapor and 1 iquid inside the tank was assumed to be $130^{\circ} \mathrm{F}$. The $130^{\circ} \mathrm{F}$ temperature was selected because the heat transfer model used a $130^{\circ} \mathrm{F}$ isothermal boundary condition at the surface of the liquid in the tank.

The exact air flowrate through Tank 241-A-105 is difficult to determine because all the tanks in $A, A X, A Y$, and $A Z$ Tank Farms are on a common exhaust system (Building 702-A), but Kazer and Veneziano (1978) has estimated this flow rate to be between 150 and 660 cubic feet per minute (CFM) with the more likely value closer to 150 CFM. Both the 150 and the 660 CFM flow rates were used to establish a problem bounding condition.

\subsubsection{Heat Boundary Conditions}

The heat input boundary condition is applied to the wa::er in the bottom of the tank. The actual value added is listed in Table 4 . This heat is the amount calculated by the HEATING7 model, which was being removed through the boundary condition, and approximated the air flow rate through the tank.

\subsubsection{Additional Boundary Condition}

As shown in Figure 6 , an inlet water flow rate was assumed. This boundary condition simply added water to the tank at a rate approximately equal to the evaporation rate so that a constant liquid level was maintained. The inlet temperature of this water was assumed to be $50^{\circ} \mathrm{F}$. Any heat removed from the tank, because of leaking cooling water, does not affect this assumption because the heat applied to the FATHOMS model is the heat calculated by the HEATING7 model, which was released to the ventilation.

\subsection{HEAT TRANSFER RESULTS}

Based upon the model assumptions previously described, the HEATING7 model was used to establish the amount of heat being removed from the tank by the ventilation air. The model validity was verified by checking the results with measured conditions in the tank. 
Thermocouple readings from the laterals underneath the tank are shown in Figures 7 through 10. Each of these figures show the temperature-time history of the thermocouples located in each of the laterals. Two steady-state HEATING7 models were developed, one to match the 1968 conditions and the other to match the 1977 conditions. These model outputs were then compared to the actual temperature reading $2 \mathrm{ft}$ underneath the tank shown in Figures 7 through 10. Figures 11 and 12 show temperature contour plots at the same depth as the laterals underneath the tank for the $? 968$ and 1978 HEATING7 models, respectively. This position of the laterals underneath the tank are superimposed on the contour plots for easier temperature comparison between the data in Figures 11 and 12 and the data in Figures 7 through 10 . Comparison of temperatures and positions from the contour plots show good agreement with temperatures recorded in Figures 7 through 10 .

The calculated contour plots show a local hot spot located roughly underneath the bulged 1 iner. This hot spot is shown more effectively on the surface plots shown in Figures 13 and 14 for the 1968 and 1978 time period, respectively. This hot spot was previously thought to be caused by heat generating sludge that leaked into the void space underneath the bulge, but the HEATING7 model has no localized heat generation rate underneath the bulge. Based upon the HEATING7 model assumptions, it is felt that this hot spot exists because the bulged liner extends above the liquid level of the tank, and thus, it is cooled only by the tank ventilation air while the rest of the tank is covered with water and is cooled more effectively.

In 1979, it was felt that the heat content of Tank 241-A-105 had decayed enough to discontinue the cooling water additions and put the tank on a portable exhauster air cooling system only. This portaile exhauster system operated until it was shut down on March 31, 1989. At that time, the temperatures in the laterals underneath the tank started to rise and kept rising until the exhauster was restarted on March 17, 1990. This temperature rise, which was a direct result of the exhauster failure, provided a good set of data for further verification of the heat transfer model.

The 1978 steady-state model output was used to start a transient calculation that modeled the portable exhauster operation until it was shut down on March 31, 1989. At this point, the model boundary conditions were changed so no air entered the tank and the resulting temperatures were compared with measured lateral temperatures for that same time period. ihe model temperature rise predictions compared with the measured lateral temperature of thermocouple 28 are shown in Figure 15 . This figure presents three curves. The solid line shows the temperature rise of thermocouple 28 in the lateral underneath the tank. The short dashed line is based on the iritial assumed heat generation rate used by Everly and Bath (Appendix A) $\left(29.47 \mathrm{Btu} / \mathrm{h} \cdot \mathrm{ft}^{3}\right)$. The long dashed line is based on a heat generation rate selected to best fit the temperature rise of thermocouple 28 . The first heat generation value for this curve $\left(19 \mathrm{Btu} / \mathrm{h} \cdot \mathrm{ft}^{3}\right)$ is in the tank and the second value (1.6 Btu/h. $\left.\mathrm{ft}^{3}\right)$ is under tha tank. As seen, the model predictions using the 19 and $1.6 \mathrm{Btu} / \mathrm{h} \cdot \mathrm{ft}^{3}$ volumetric heat generation rates in 1978 provide a reasonable fit to the measured temperature both in magnitude and rate of temperature increase. As noted in the assumption section, the 19 and $1.6 \mathrm{dt}: \mathrm{h} \cdot \mathrm{ft}^{3}$ rates were the base case 1978 values. Actual transient heat generations were decayed using Equation 3 for both heat generation terms. 
WHC-EP-0410

Figure 7. Lateral Number 1 Temperature History.

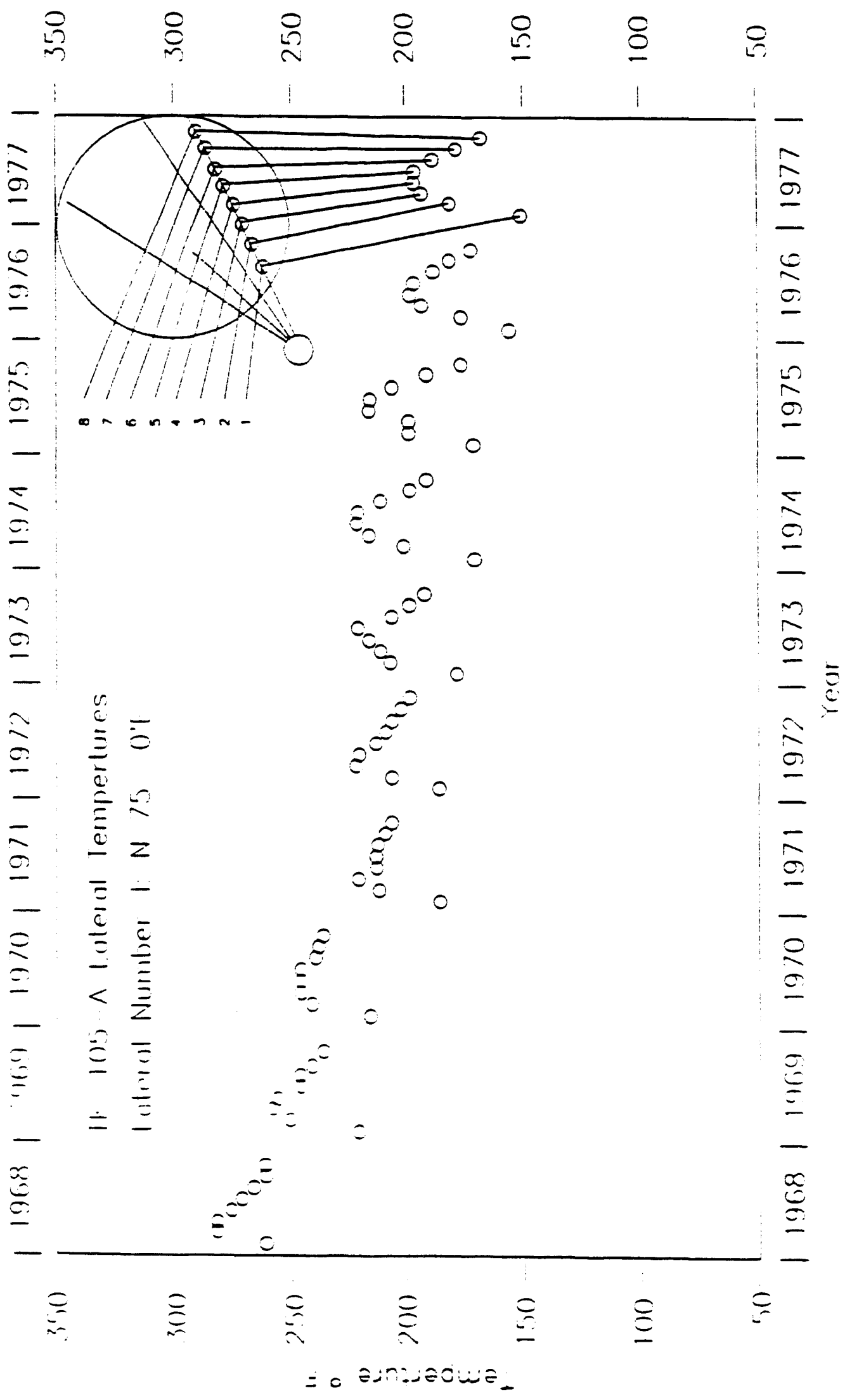


WHC-EP-0410

Figure 8. Lateral Number 2 Temperature History.

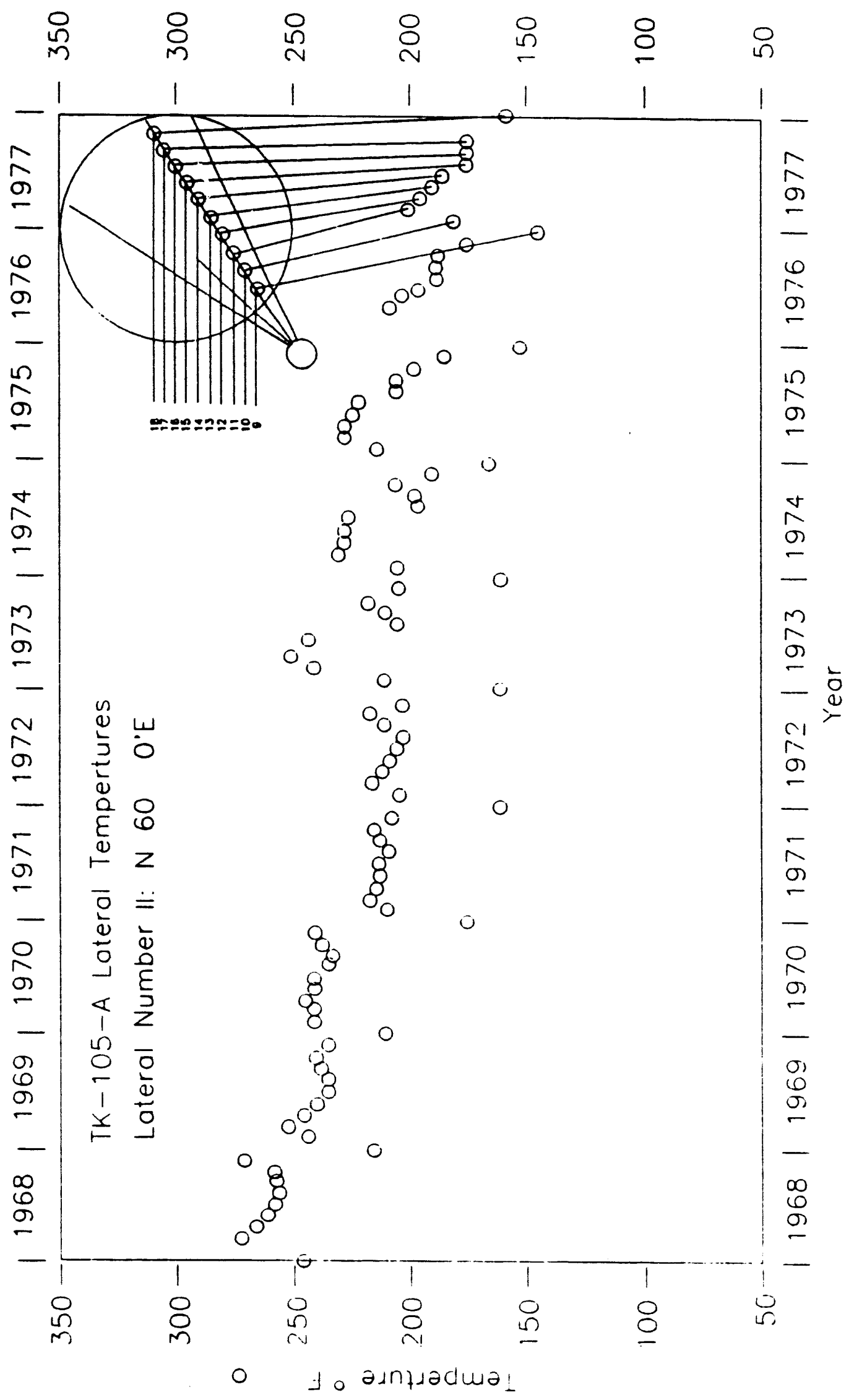


WHC-EP-0410

Figure 9. Lateral Number 3 Temperature History.

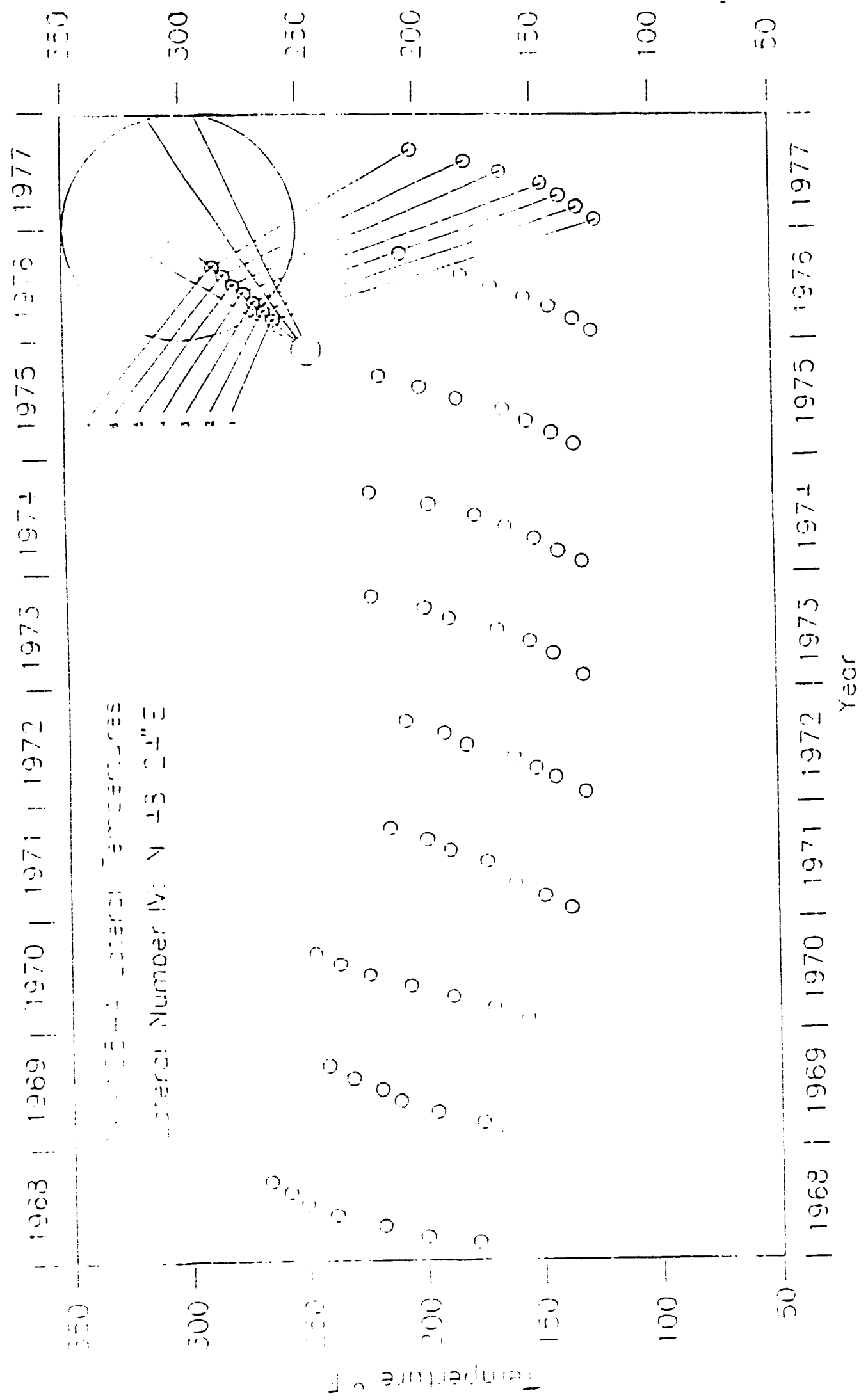

17 
WHC-EP-0410

Figure 10. Lateral Number 4 Temperature History.

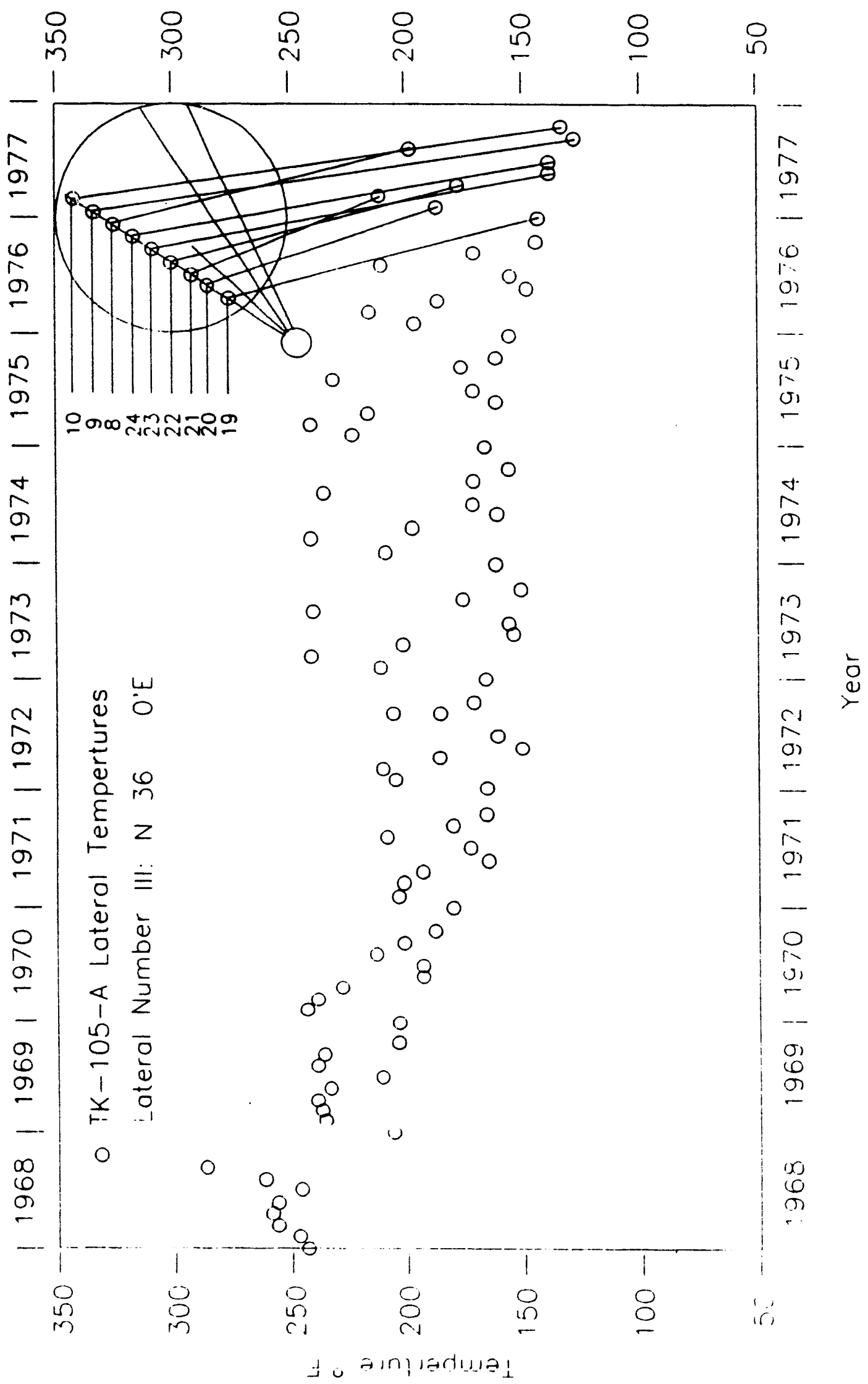


Figure 11. Calculated Temperature Contour $2 \mathrm{ft}$ Below Tank Bottom, 1968.

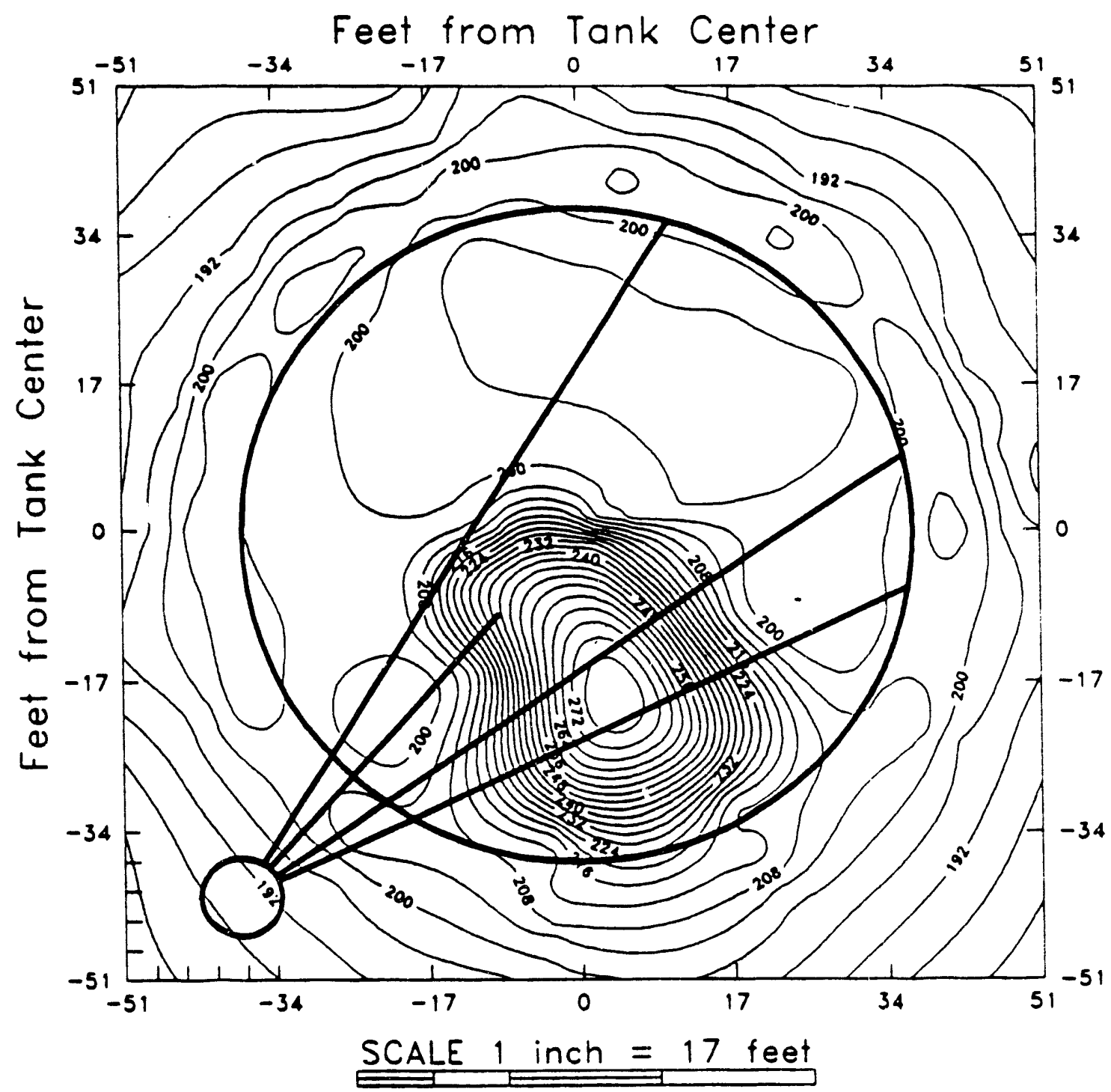


Figure 12. Calculated Temperature Contour $2 \mathrm{ft}$ Below Tank Bottom, 1978.

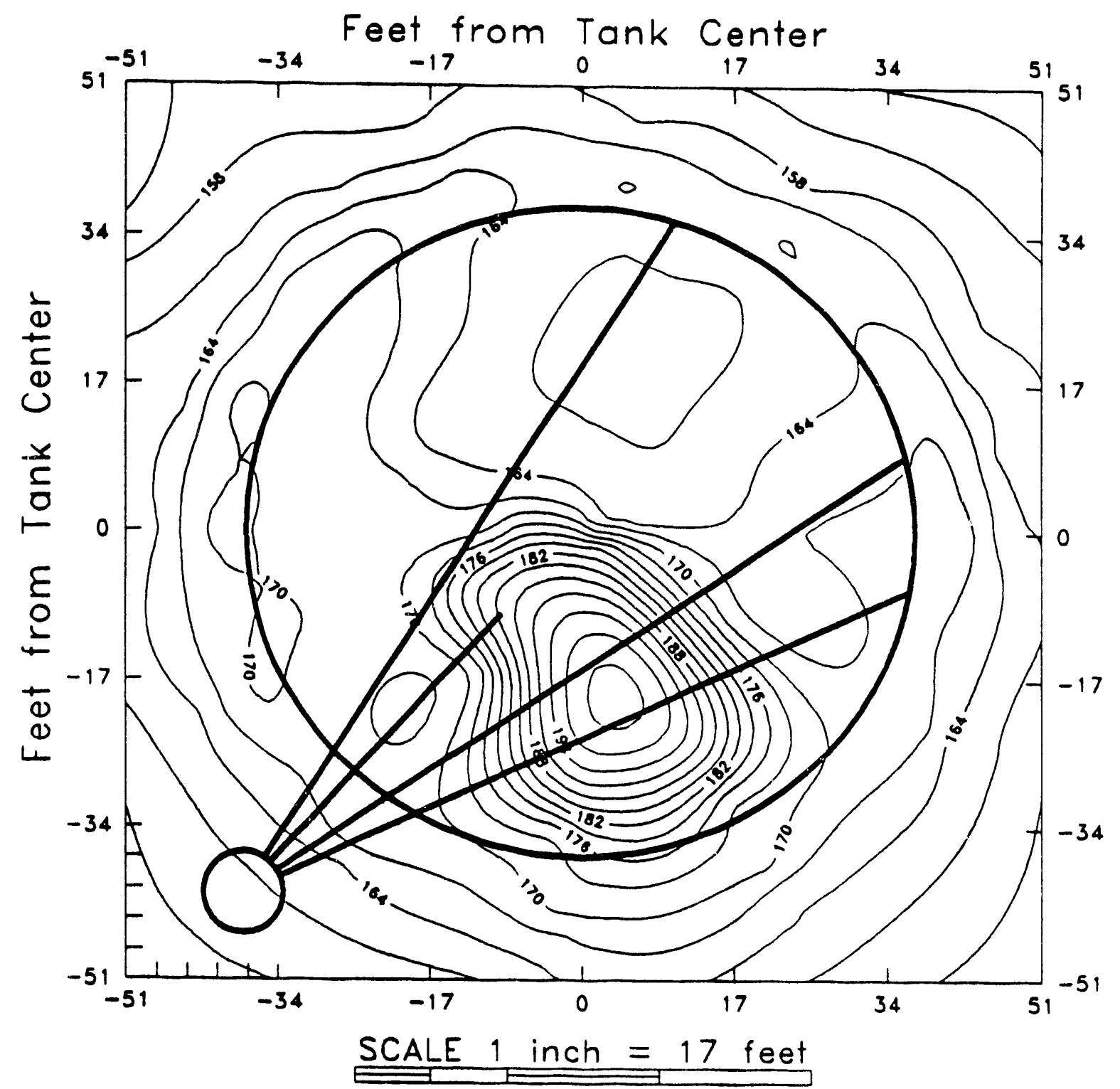


WHC-EP-0410

Figure 13. Temperature Surface $2 \mathrm{ft}$ Below Tank Bottom, 1968.

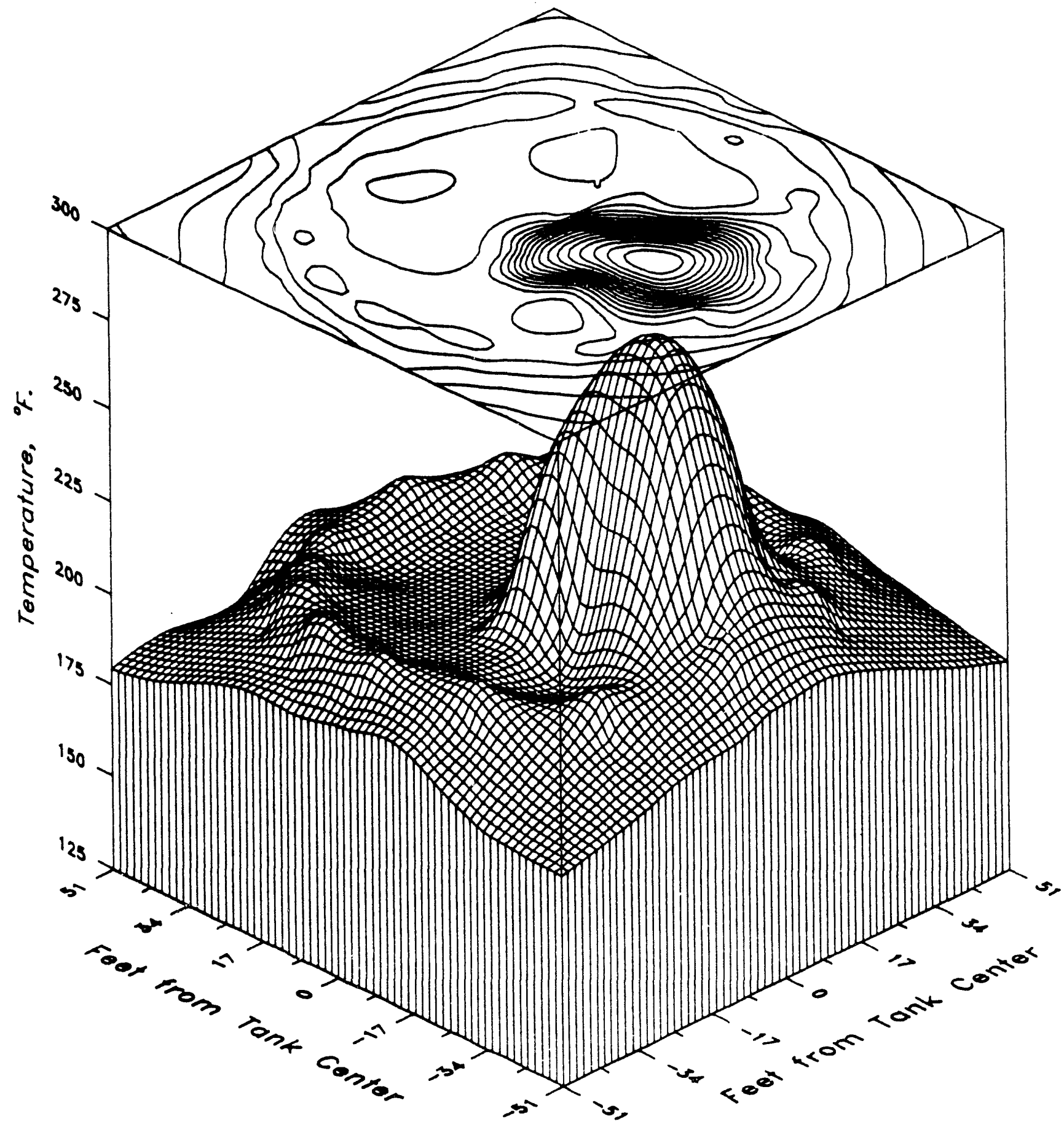




\section{WHC-EP-0410}

Figure 14. Temperature Surface $2 \mathrm{ft}$ Below Tank Bottom, 1978.

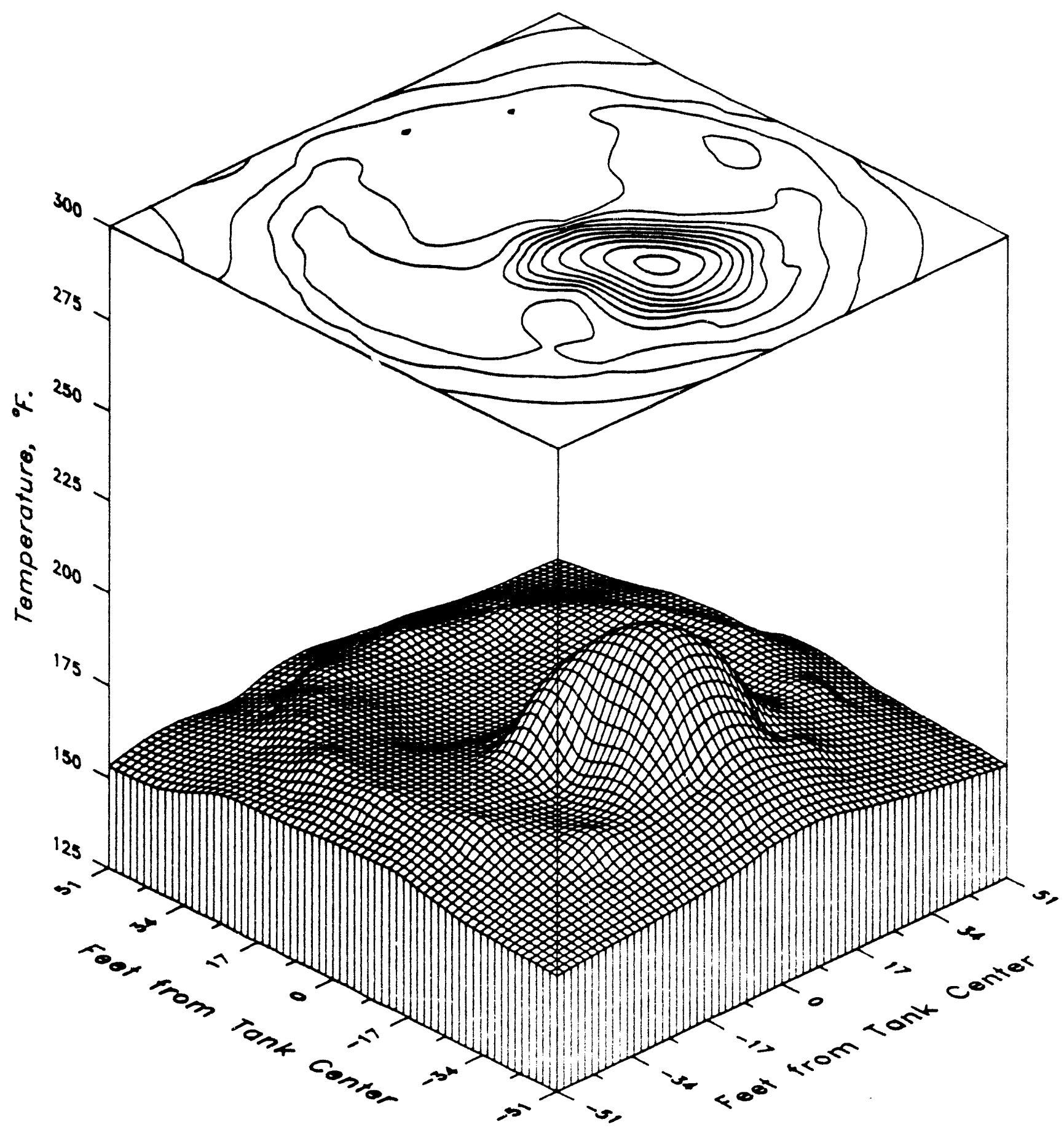


Figure 15. Temperature $2 \mathrm{ft}$ Below Tank After Portable Exhauster Failure.

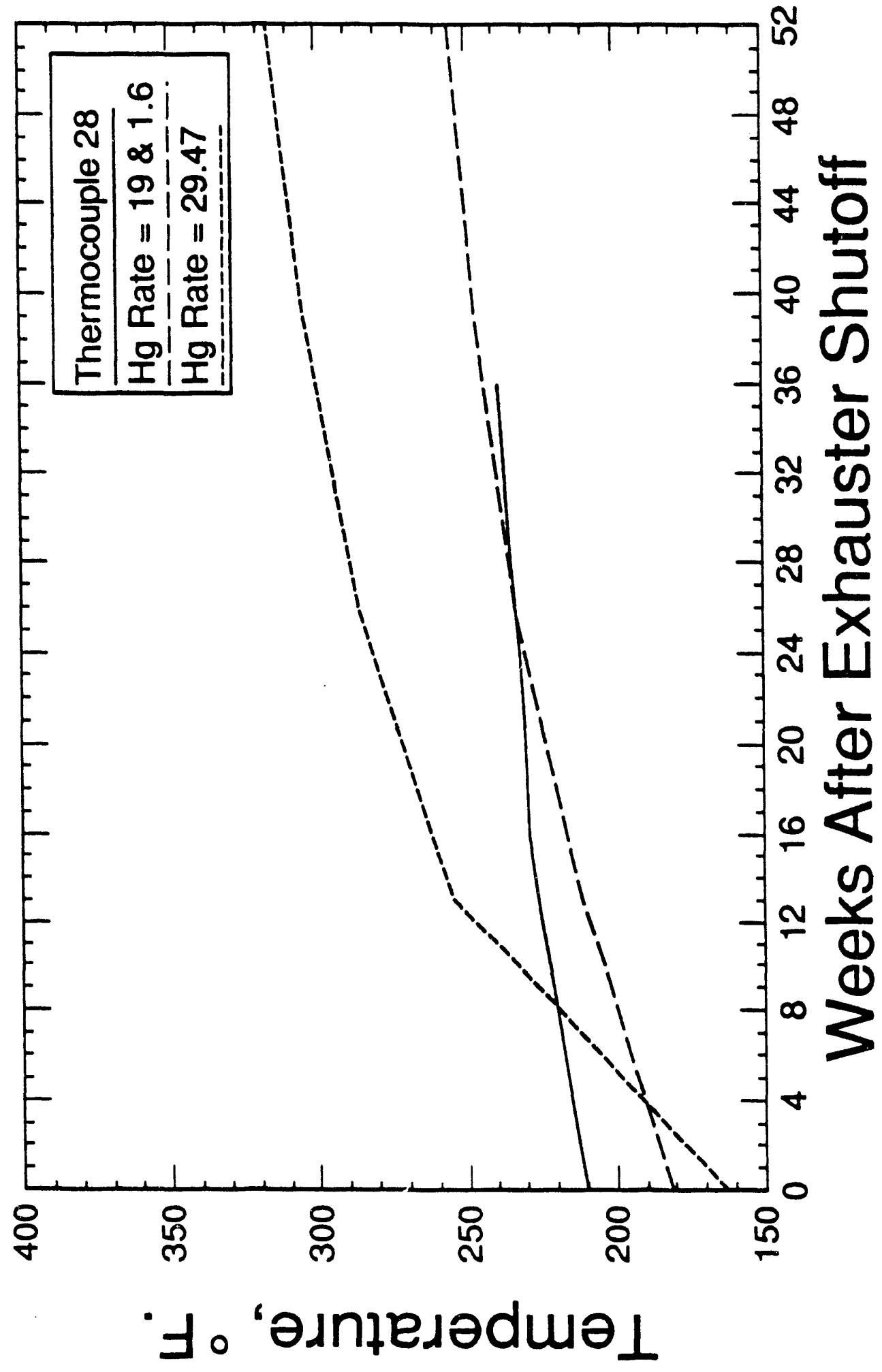


The agreement between the model predictions and actual measured temperatures for the 1968 and 1978 steady state runs, as well as for the transient runs when the portable exhauster was down in 1989, provide a high degree of confidence that the assumed model heat generation rate is close to reality.

\subsection{EVAPORATION RESULTS}

Two bounding ventilation air flow rates were considered for the evaporation calculations: 150 and 660 CFM. Based upon the heat input and average atmospheric conditions discussed previously, the tank vapor space and liquid temperatures are shown in Figures 16 and 17 for the 150 and 660 CFM air flow rate, respectively. Each of these figures show the seasonal temperature variations of the vapor space and liquid inside the tank. As expected, the temperature variation for the 660 CFM case is wider than for the 150 CFM case. Sludge temperatures at the $1.5 \mathrm{ft}$ level taken from "Tank Farm - 241-A - Status Report" records (Appendix C) are shown in Table 6.

These sludge temperatures correspond to the liquid temperature in the FATHOMS model and agree reasonably well with the 150 CFM case shown in Figure 16. As stated in Section 2.2.2, the 150 CFM case is considered more likely.

Table 6. S7udge Temperatures, Tank 241-A-105

$1.5 \mathrm{ft}$ from Tank Bottom.

\begin{tabular}{|c|c|}
\hline Date & Temperature, ${ }^{\circ} \mathrm{F}$ \\
\hline Oct 31, 1971 & 119 \\
\hline Nov 13, 1973 & 117 \\
\hline May 13, 1974 & 135 \\
\hline
\end{tabular}

The water evaporated from the tank based upon the bounding ventilation air flow rates are shown in Table 7 .

Examination of the data presented in Table 7 shows that there is a decreased total evaporation volume for the 660 CFM case. In addition, there is a significant drop in the evaporation rate between the first and second year for the 660 CFM case. The evaporation drop between the first and second year is caused by the initial temperature assumption of $130^{\circ} \mathrm{F}$ at the beginning of the computer simulation. This causes a higher initial calculated evaporation rate than when the model brings the tank vapor temperatures down to the $80^{\circ} \mathrm{F}$ temperature range predicted for the $660 \mathrm{CFM}$ air flow rate. In both cases, the air exiting the tank is at, or very close to, saturated conditions. Because of the increased air flow for the 660 r.FM case, the exiting air temperature is lower than for the 150 CFM case. This lower temperature causes a decrease in the total amount of water in the air at saturated conditions. 
WHC-EP-0410

Figure 16. 150 CFM Air Flow Rate.

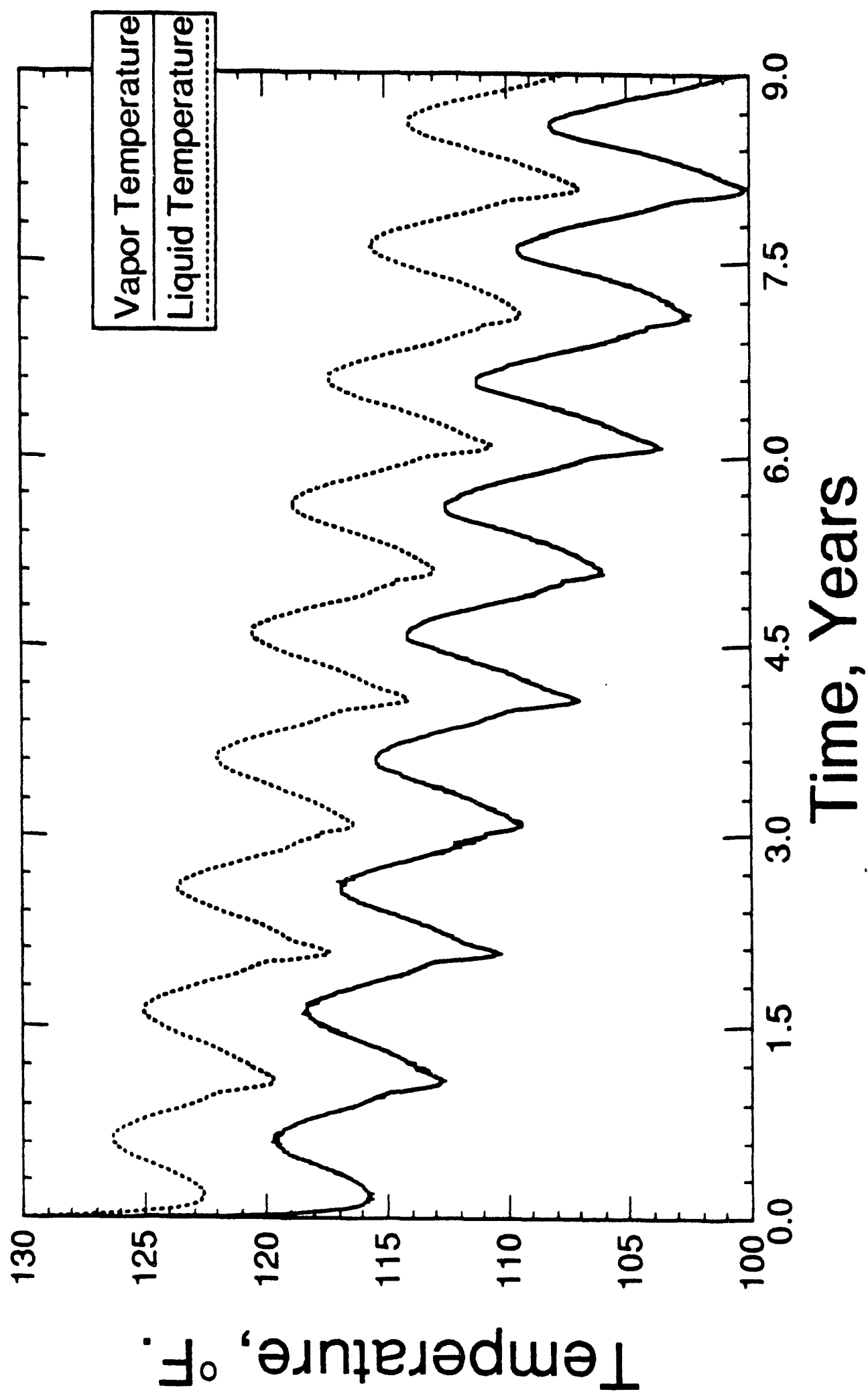


WHC-EP-0410

Figure 17. 660 CFM Air Flow Rate.

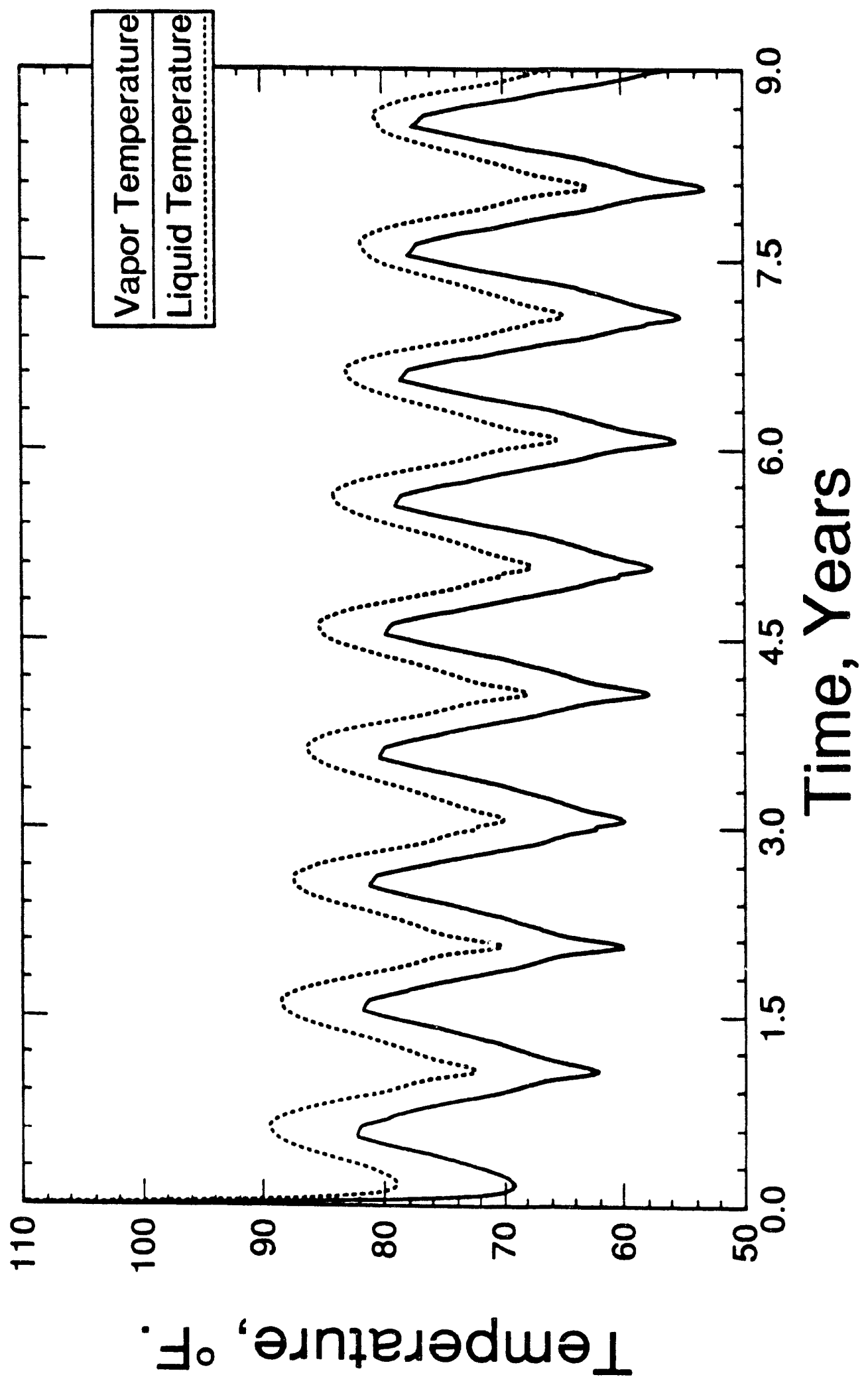


Table 7. Water Evaporated from Tank 241-A-105.

\begin{tabular}{|c|c|c|}
\hline Year & $\begin{array}{c}150 \text { CFM air flow } \\
\text { gallons }\end{array}$ & $\begin{array}{c}660 \text { CFM air flow } \\
\text { gallons }\end{array}$ \\
\hline 1 & 56,727 & 55,373 \\
\cline { 2 - 3 } & 53,041 & 47,471 \\
\hline 3 & 50,231 & 45,199 \\
\hline 4 & 47,749 & 43,263 \\
\hline 5 & 45,099 & 41,147 \\
\hline 6 & 42,755 & 39,273 \\
\hline 7 & 40,278 & 37,295 \\
\hline 8 & 38,063 & 35,482 \\
\hline 9 & 35,740 & 33,634 \\
\hline Total & 409,683 & 378,137 \\
\hline
\end{tabular}

During actual operating conditions, the 660 CFM air flow rate case might evaporate more liquid than the 150 CFM case. The heat input to the water in the FATHOMS model was based upon HEATING7 calculations which used a $130^{\circ} \mathrm{F}$ boundary temperature. The boundary temperature matched the vapor space temperature calculated by FATHOMS for the 150 CFM flow rate case only. If the air flow rate was actually increased to $660 \mathrm{CFM}$, the tank vapor temperature would be lower, causing additional tank heat to be removed by the ventilation system. If a lower HEATING7 boundary temperature had been used, more heat would be removed by the air space and this additional heat would evaporate more water in the FATHOMS model.

\subsection{CONCLUSIONS}

This study calculated the amount of cooling water evaporated from Tank 241-A-105 from 1970 through 1978, when the tank was cooled by maintaining a minimum level of water in the tank. These calculations were completed by developing a heat transfer model and benchmarking the results with measured tank temperatures. Results from this benchmarked model were then used to calculate the amount of water evaporated.

In order for the heat transfer model to match measured data, a heat generation rate underneath the tank had to be added in addition to the heat inside the tank. During the 1970 through 1978 time period, this heat generation region underneath the tank had to be reduced faster than can be accounted for by radiolytic decay, which indicates that a leak plume is 
underneath the tank and was washed deeper into the soil column during the time period wen cooling water was added. The concentration of the heat generation region under the tank had to be reduced by $60 \%$ of its initial 1968 value by 1978. From 1978 to the present, the heat generation rates for transient analyses used the radioactive decay functions for both the in tank and under tank heat generation. This indicates that after the cooling water was discontinued, the heat generation migration under the tank stopped.

There is a localized hot spot underneath the tank that corresponds to the location of the bulge in the bottom. This hot spot has historically been attributed to sludge that leaked underneath the bulge. The model does not have a localized higher heat generation rate underneath the bulge, but still predicts the hot spot as measured in the tank. These results indicate the hot spot was caused because the bulge is extending into the air region and is only cooled by air while the rest of the tank bottom is cooled by the wacer. The hot spot in the middle of the tank still exists, even though the tank is now dry. Presently, this condition is attributed to the soil underneath the center of the tank, which is more effectively insulated by the tank than the soil underneath the perimeter of the tank.

The results of the heat transfer model was used as input to calculate the total amount of water evaporated from Tank 241-A-105 from 19;0 through 1978. Based upon this heat transfer model, between 378,000 and 410,000 gallons of water were evaporated during this time period.

\subsection{REFERENCES}

Beard, S. J., et a1., 1967, Purex TK-105-A Waste Storage Tank Liner Instability and its Implications on Waste Containment and Control, ARH-78, Atlanti: Richfield Company, Richland, Washington.

Burke, T. M., 1990 CAP/FATHOMS Code User's Manual, WHC-SD-FM-ER-009, West innhouse Hanford Company, Richland, Washington.

Carl, B. P., 1978, Elimination of Water Addition to Tank 105-A, 241-A Tank Farm Process Test Plan 781 (Part 1), RHO-CD-625, Rockwell Hanford Company, Richland. Washington.

Childs, K. W., 1991, Heating 7.1 User's Manual, draft copy, K/CSD/TM-96, Mart in Marietta, Oak Ridge, Tennessee.

Garfield, J. S., 1975, Anticipated Natural Air Breathing Rate for Underground Tanks, ARH-CD-256, Atlantic Richfield Company, Richland, Washington.

Kazer, J. D. and T. B. Veneziano, 1978, Tank 105-A Stabilization Progress Report, RHO-CD-255, Rockwell Hanford Company, Richland, Washington.

Welty, J. R., C. E. Wicks, and R. G. $\therefore:$ ? son, 196?. Fundamentais of Momentum, Heat and Mass Transfer, John Wiley and Sons, Inc., pp 341. 
WHC, 1991, Waste Storage Tank, Composite Section. Drawing Number H-2-55911, Westinghouse Hanford Company, Richland, Washington.

WHC, 1989, Nusar N Reactor Updated Safety Analysis Report - Amendment 20, WHC-EP-0240-1, Westinghouse Hanford Company, Richland Washington. 
WHC-EP-0410

This page intentionally left blank. 
WHC-EP-0410

APPENDIX A

HEAT TRANSFER STUDY ON TANK 241-A-105

APP $A-i$ 
WHC-EP-0410

This page intentionally left blank. 
$\cdots \cdots-\vdots: \because:$

August 10,1978

T. B. Veneziano

Tank Farm Process Engr'g

$2750-\varepsilon / 200$ East

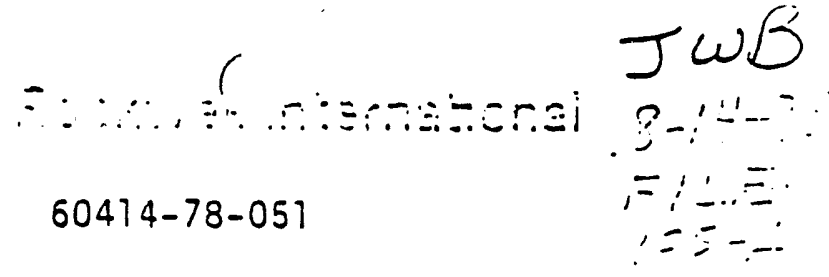

D. W. Everly - S. S. Bath Waste Processing Technology $2750-E / 200$ East

Ext. 240

Heat Transfer Study on Tank 105-A

\section{Introduction}

A steady state heat transfer study on Tank 105-A was performed using the computer program, HEATING 5. With data provided by Tank Farm Process Engineering (TFPE) and an assumed sludge material profile, a computer model was prepared. The program was run for variable amounts of total heat generation of sludge material to match a temperature profile two feet below the bottom surface of the tank provided as data oy TFPE.

\section{Summary}

The results of the study show that a volume of $2365 \mathrm{ft}^{3}$ of sludge material with a constant heat generation of $29.47 \mathrm{BTU} / \mathrm{hr}-\mathrm{it}^{3}$ and the assumed sludge material profile should have a maximum temperature of $215^{\circ} \mathrm{F}$ at a level two feet below the tank. With 1000 gallons per week of water added to Tank 105-A, a boundary condition of $130^{\circ} \mathrm{F}$ was used on the inner surfaces of the tank. If water is no longer added to the tank, the boundary condition on the tank surface is removed. The maximum steady state temperature in the tank under these conditions is over $500^{\circ} \mathrm{F}$.

Data

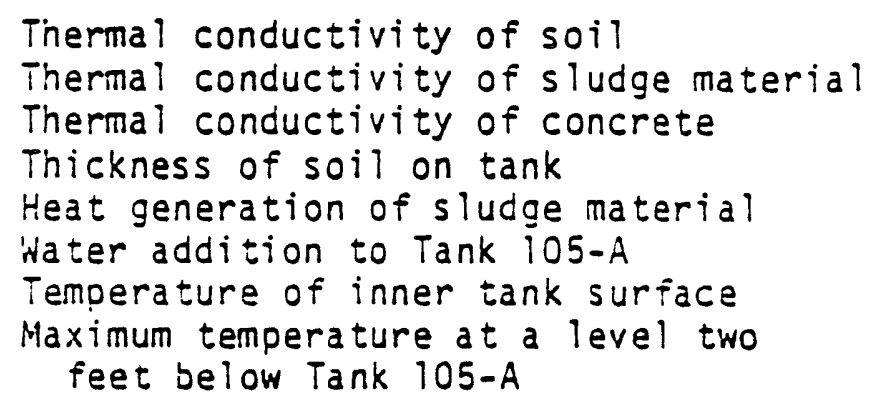

$\begin{array}{ll}0.25 & \text { BTU/hr-ft- }{ }^{\circ} \mathrm{F} \\ 0.25 & \text { BTU/hr-ft- }{ }^{\circ} \mathrm{F} \\ 0.25 & \text { BTU/hr-ft- }{ }^{\circ} \mathrm{F} \\ 8.0 & \text { Feet } \\ 29.47 & \text { BTU/hr-ft } 3 \\ 1000 & \text { Gallons/week } \\ 130^{\circ} \mathrm{F} & \\ 215^{\circ} \mathrm{F} & \end{array}$

Assumptions

1. A constant temperature of $80^{\circ} \mathrm{F}$ was assumed for the soil surface boundary condition.

2. The temperature of the water table, a depth of 200 feet below the soil surface: was constant at $70^{\circ} \mathrm{F}$. 


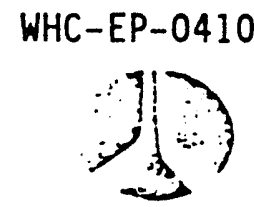

T. B. Veneziano

Page 2

August 10,1978

3. An insulated boundary was assuned between storage tanks.

\section{Discussion}

The computer model used for this heat transfer study is shown in figures 1 and 2. This model was prepared from "An Estimate of Bottom Topography, Volume and Other Conditions in Tank 105-A, Hanford, Washington" by WoodwardClyde Consultants and an estimate of sludge material under the bulge in the liner at the bottom of the tank by $T$. B. Veneziano of TFPE.

Additional data provided by TFPE was a heat generation rate of 29.47 $\mathrm{BTU} / \mathrm{hr}-\mathrm{ft}^{3}$ for the siudge material, a maximum temperature of $215^{\circ} \mathrm{F}$ at a level two feet below the tank, a temperature of $130^{\circ} \mathrm{F}$ on the inner suriace of the tank, and the addition of 1000 gallons per week of water to Tank 105-A. Assuming a $130^{\circ} \mathrm{F}$ boundary condition inside the tank, a series of computer runs with a variable amount of total heat generation were made to estimate the volume of sludge material. In Figure 3 , the maximum temperature two feet below the tank is plotted versus the volume of sludge material generating heat at a constant rate of 29.47 BTU/hr-ft 3 . Using the maximum temperature data, $2365 \mathrm{ft}^{3}$ is the estimated volume of sludge material. The temperature profile at two feet below the tank bottom of a computer run made with the estimated sludge material volume is shown in Figure 4. If water were no longer added to Tank 105-A, the $130^{\circ} \mathrm{F}$ boundary condition is removed. Figure 5 shows the computed temperature profile at steady state for the bottom of the tank, the location of the maximum temperatures. For the estimated sludge material volume, the maximum temperature is above $500^{\circ} \mathrm{F}$.

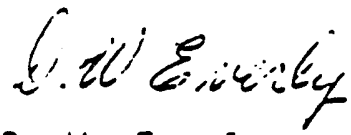

D. W. Everly

Waste Processing Technology

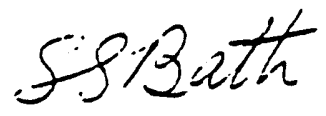

S. S. Bath

Waste Processing Technology

DWE/SSB/db

At:.

cc: w/att.

J. W. Bailey

S. S. Bath

G. D. Campbell

G. T. Dukelow

D. W. Everly

D. G. Harlow

C. O. Luchterhand

D. L. Merrick

L. A. Villalba

R. A. Zinsli 
WHC-EP-0410

TANK 105A - R, ECOO20INATES

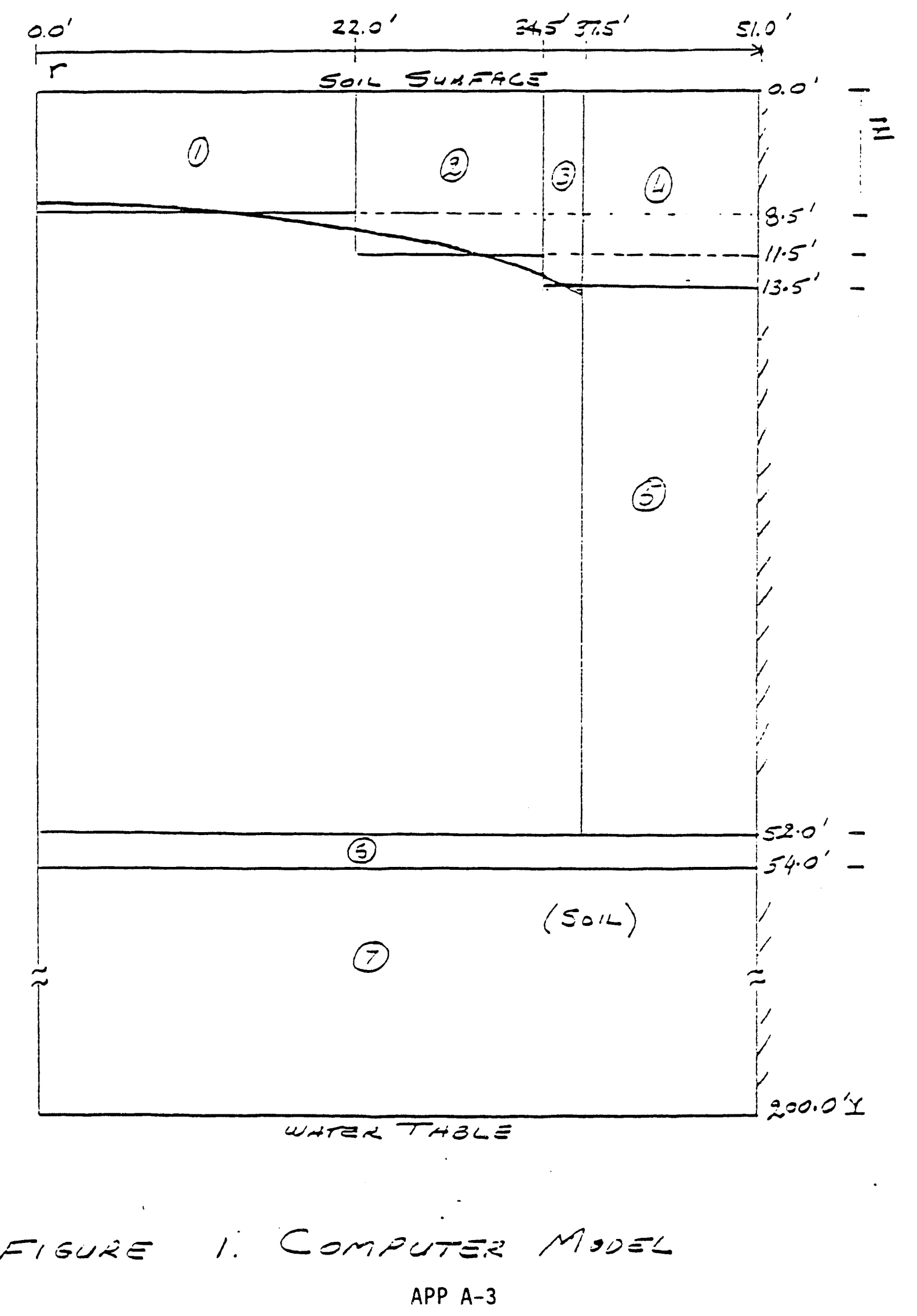


WHC-EP-0410

TANK $105 A$

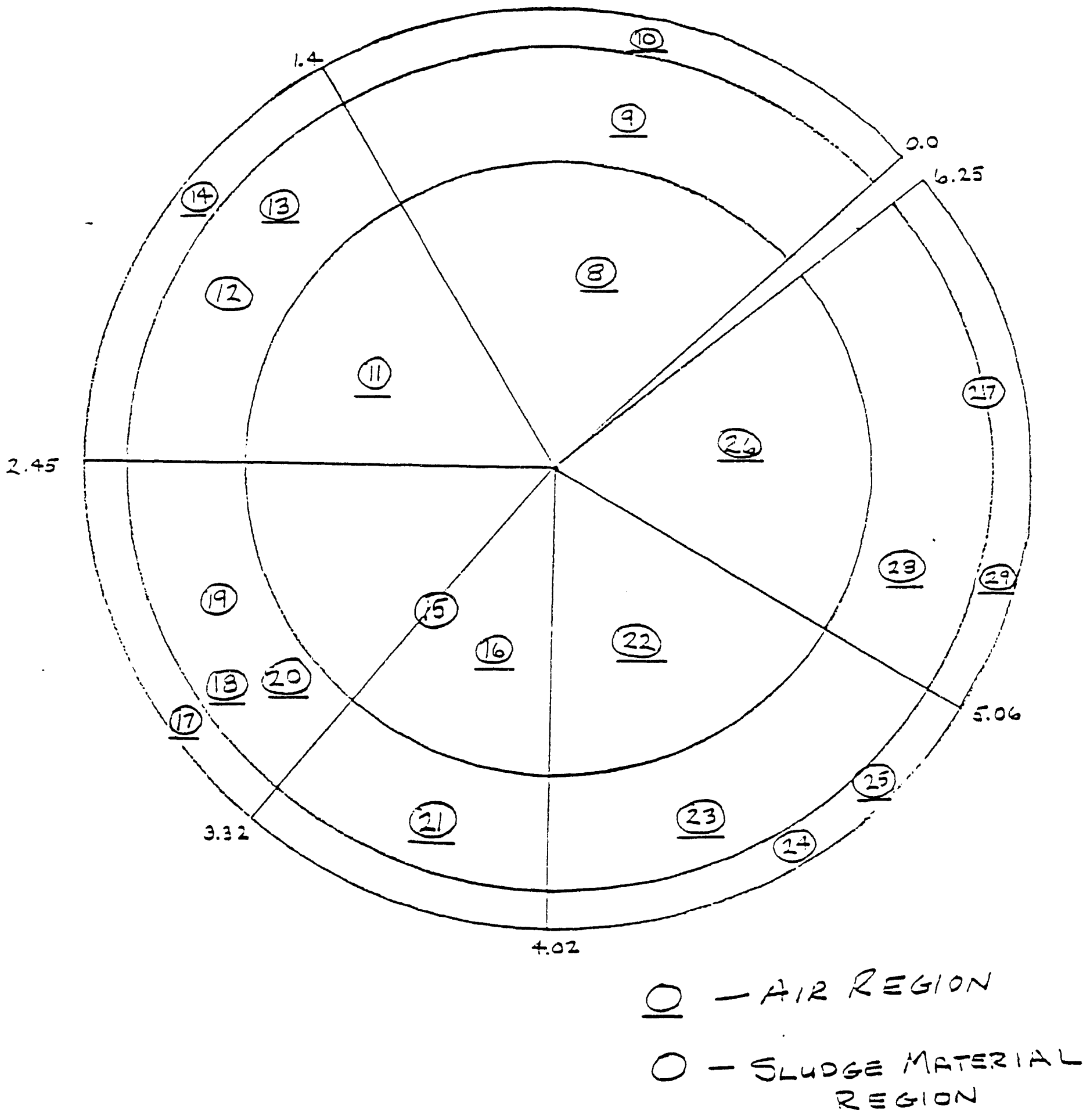

F/GURE2. COMPUTER MOOEL 


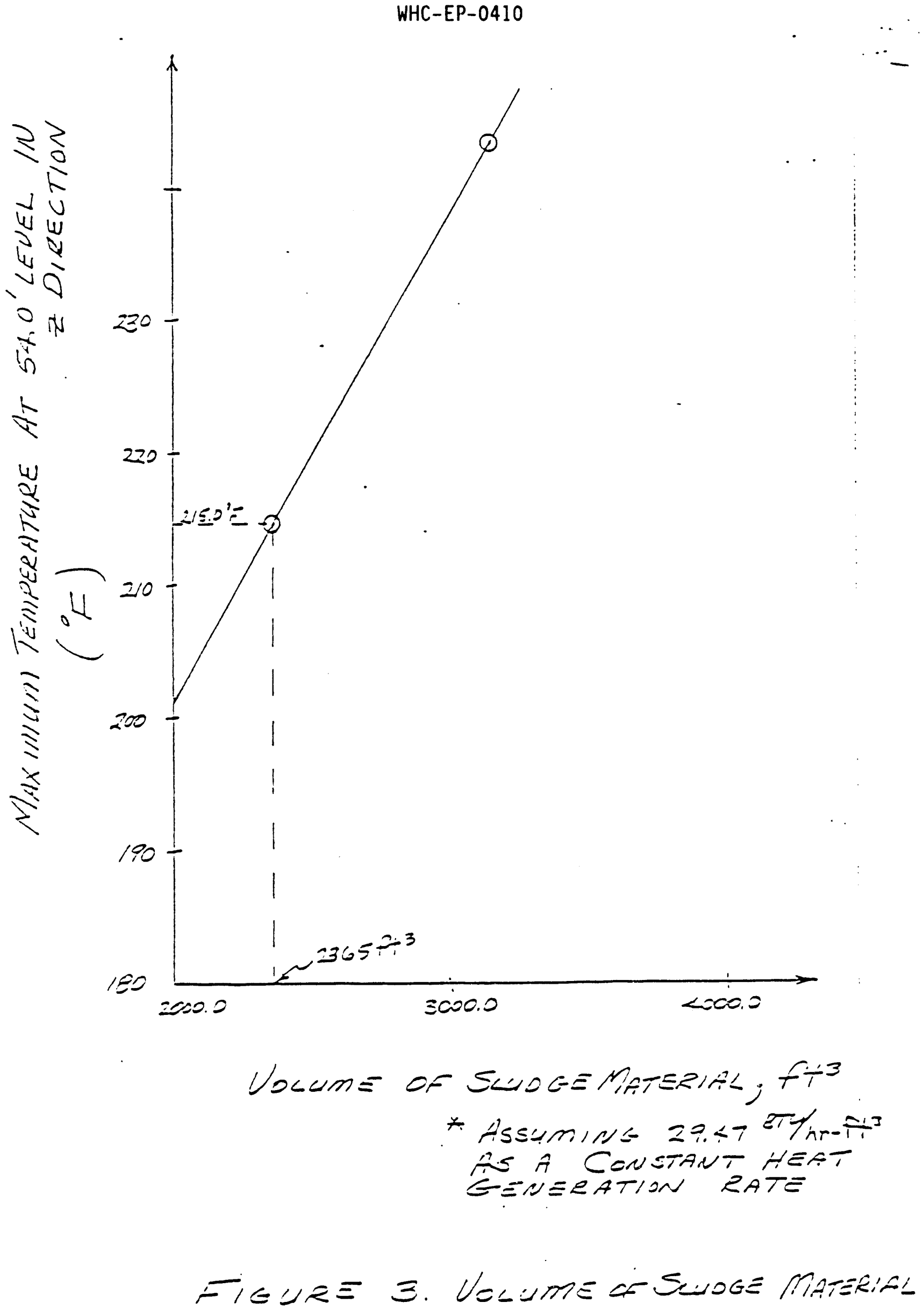

APP $A-5$ 
WHC-EP-0410

TANK $105 A$

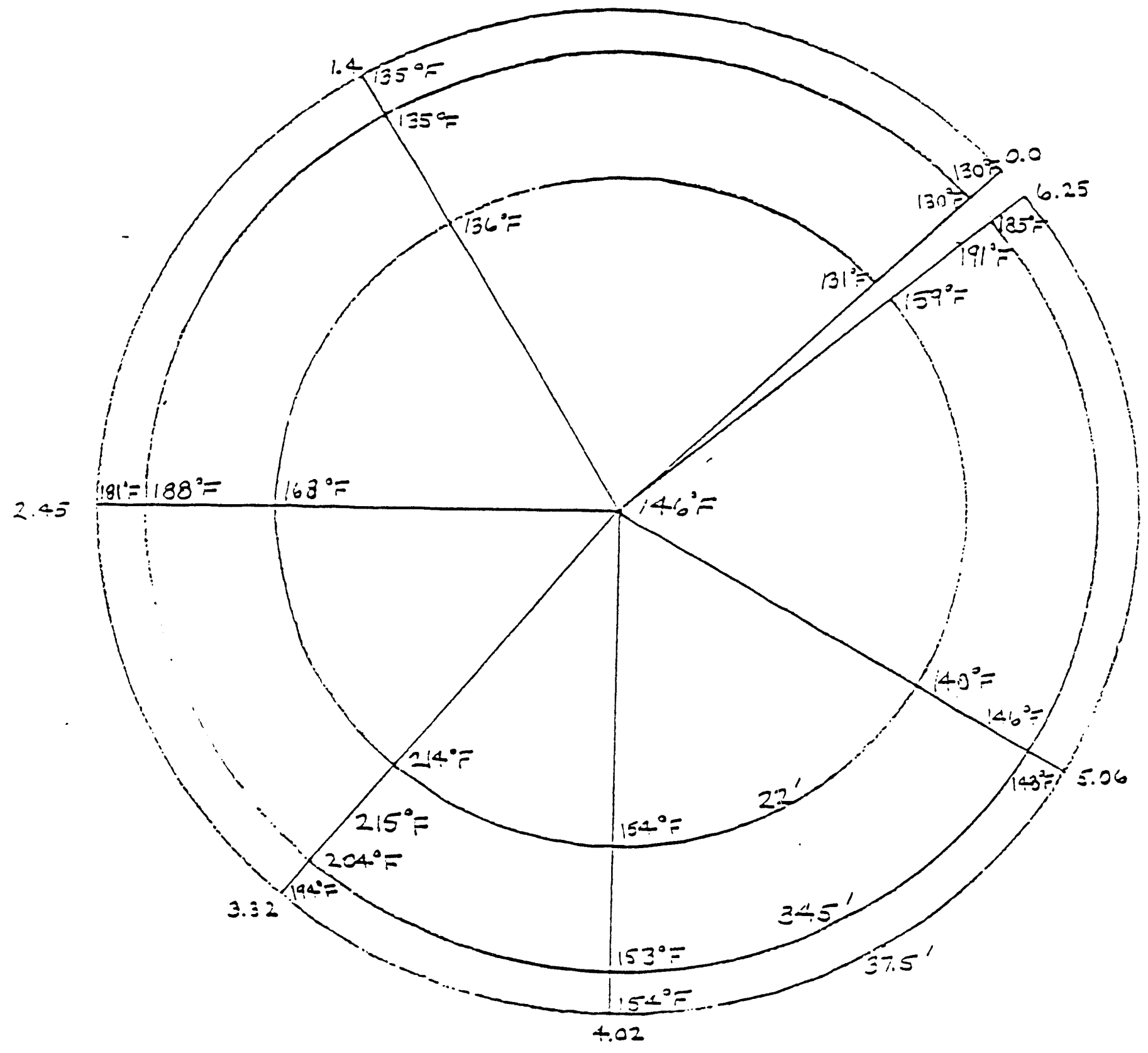

$$
\begin{aligned}
& \text { 2.0' 8ELOW Tras }
\end{aligned}
$$

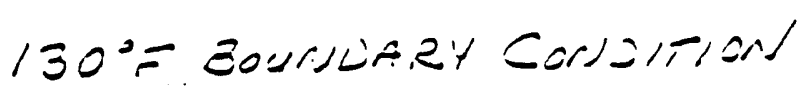

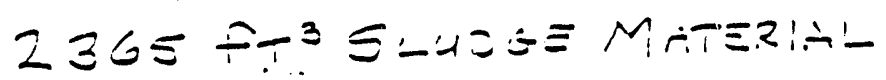

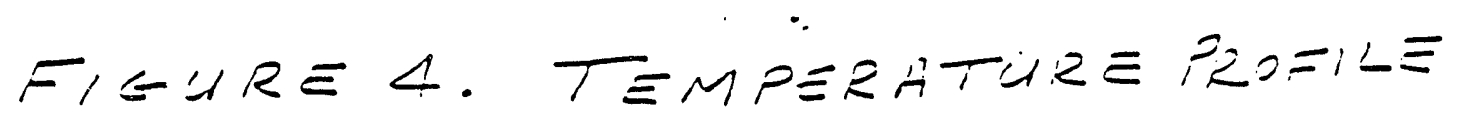


WHC-EP-0410

TANK IOSA

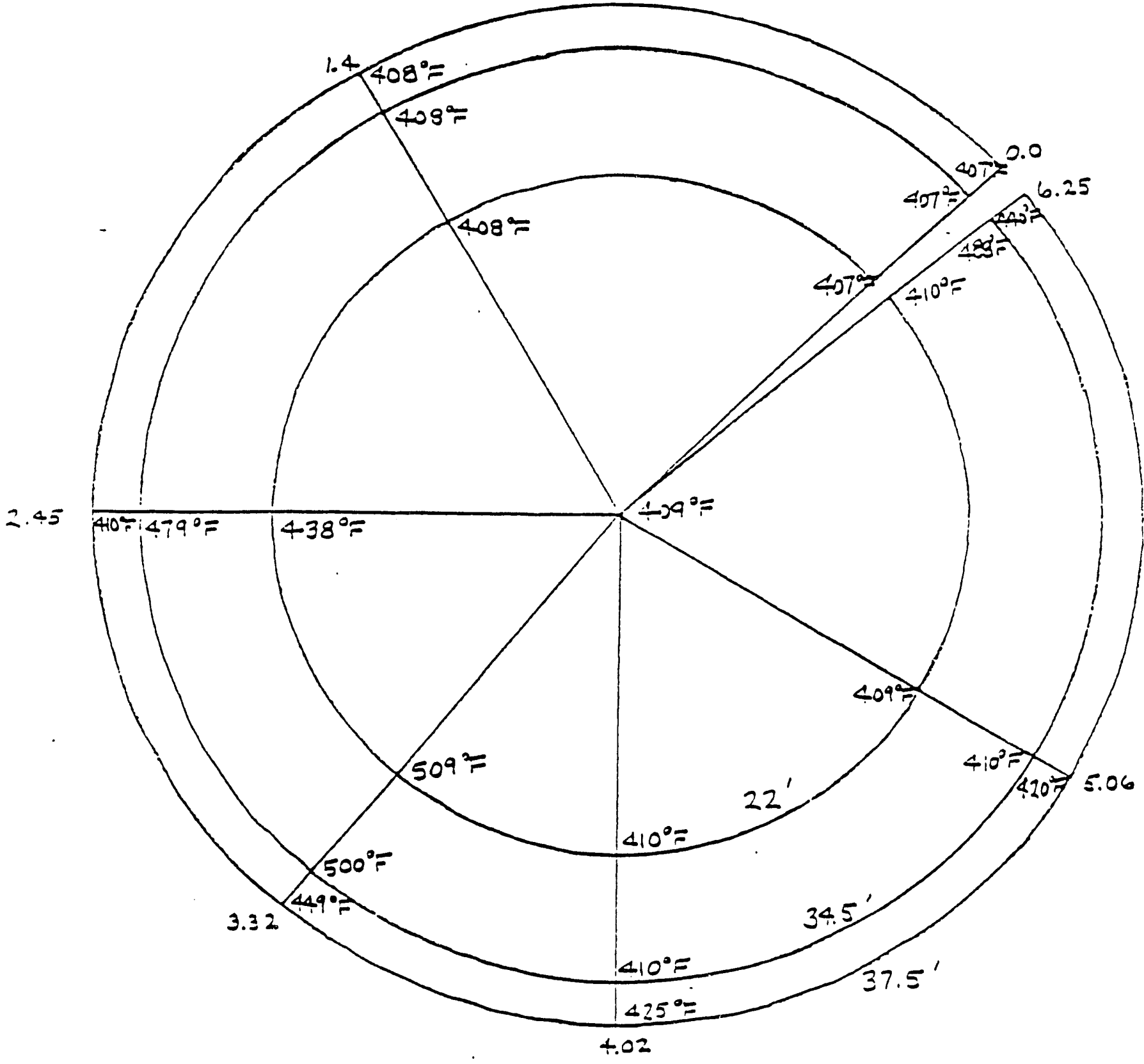

BoTTOM OE THNRK

2365 f $^{3}$ S SLUEG MATERH-

No BCUn'Dazy COROITIONJ inside TANK

Figure 5. TEMPERATULE PROFILE 
WHC-EP-0410

This page intentionally left blank. 
WHC-EP-0410

APPENDIX B

COMPOSITION AND DENSITY OF TANK 241-A-105 SOLIDS 
WHC-EP-041C

This page intentionally left blank. 


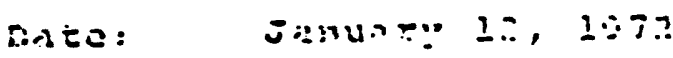

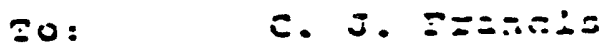

c. $: i, \quad i: \vdots \because \because \bullet=$

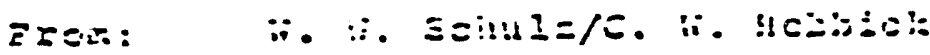

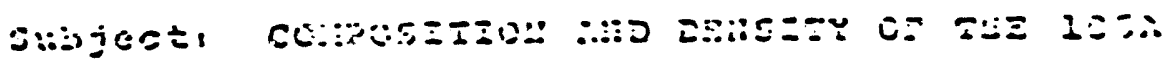
SU:三ニ

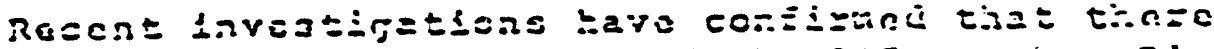

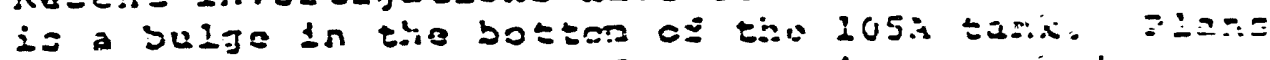

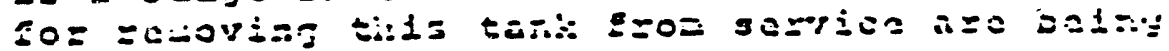

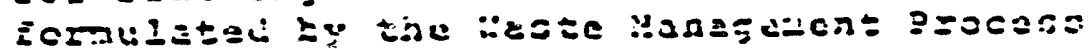

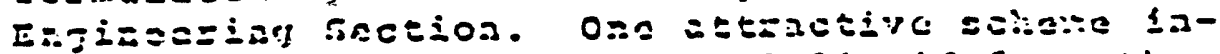

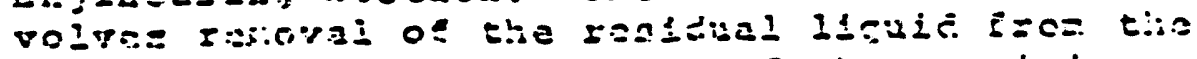

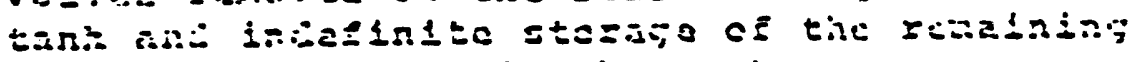
=こdtoaciige soiils dr. tic tand.

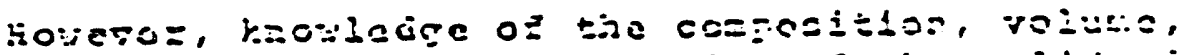

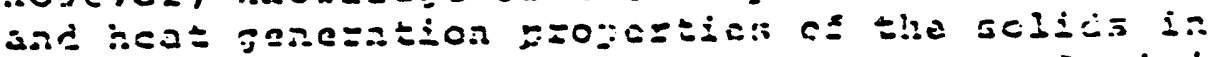

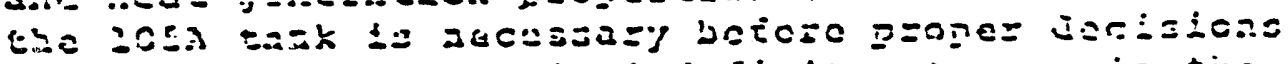

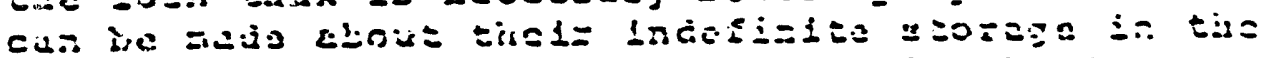

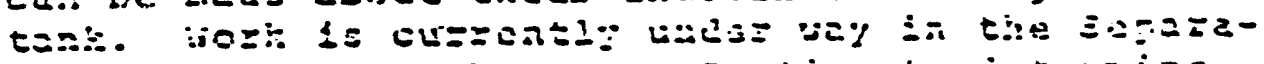

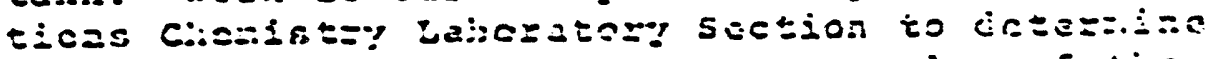

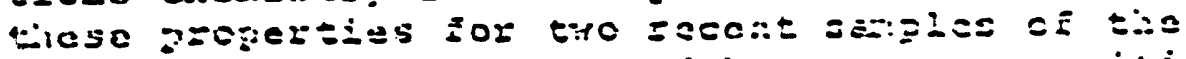

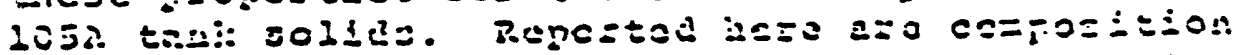

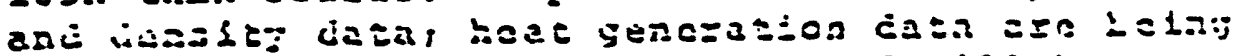

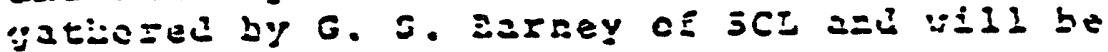

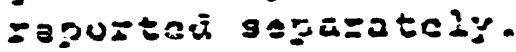

\section{RESLLTS}

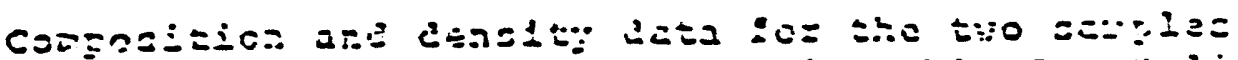

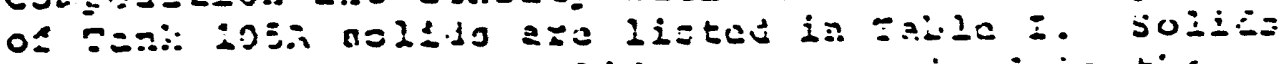

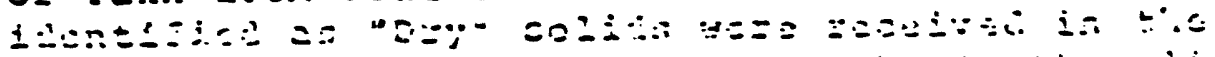

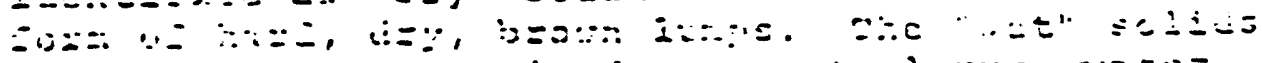

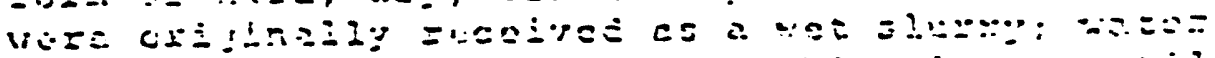

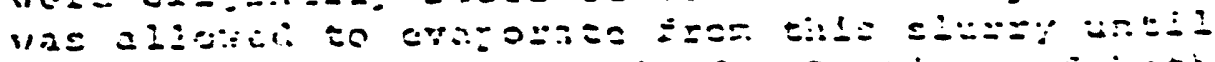

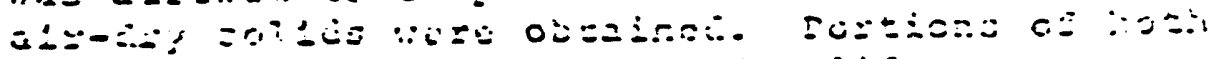

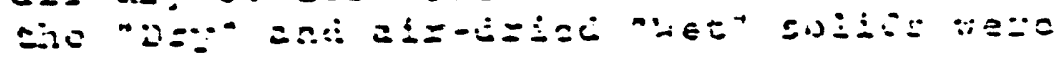

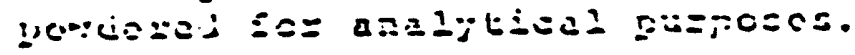

シニYc

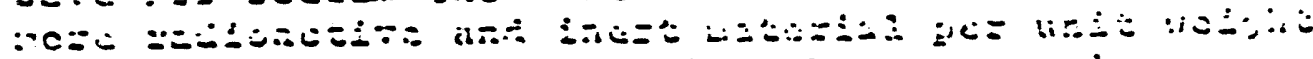
t:ב:.

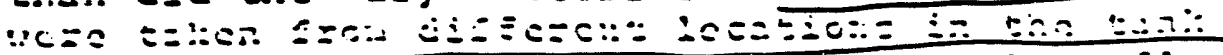

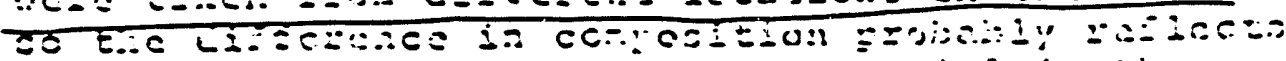

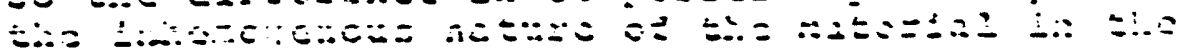
$\because$ :

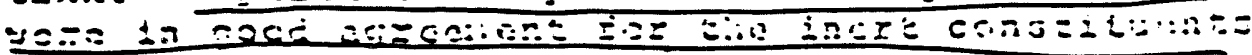


WHC-EP-0410

00593

c. J. $: 8:=\pi:=13$

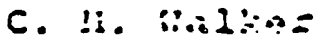

$n=5=2$

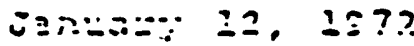

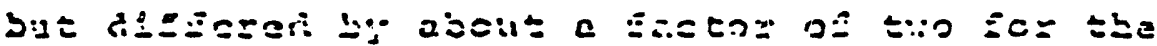

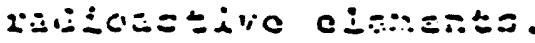

TA:EI I

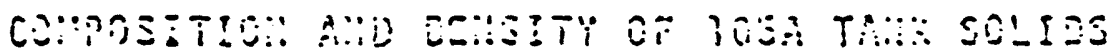

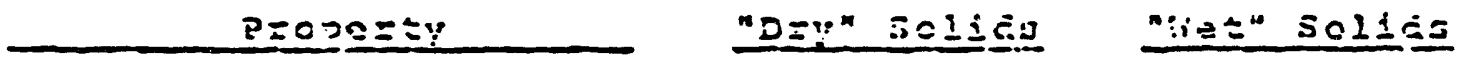

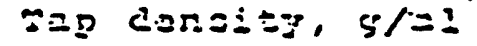

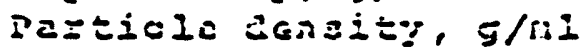

per
$C=:=0:=i=3$

泀况, 纤

$F=, \quad j / S$

is $1,5 / 2$

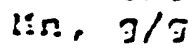

si. $\quad \mathrm{g} / \mathrm{g}$

Ii, $g /: 3$

- $0.9 / \mathrm{s} / \mathrm{s}$

is $\leq=, H C i / 3$

$1+4 \mathrm{Ca}, 110 i / \mathrm{J}$

2: ?Cs, $\mu C i / \mathrm{cj}$

105 S.

$123=\vdots, \mu E \Sigma / g$

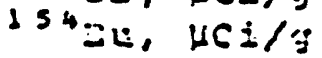

anoznsis 2a

$$
0.2 .1
$$

0.056

$0.032^{\circ}$

0.0025

0.022

$2.3=10^{-3}$

- -

13.400

620

500

420

230

35
3.54

2. 22

(a)

Noteds

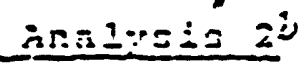

0.31

0.022

0.033

$0.00 \% 5$

$0.02=$

$2.3 \div 10^{-1}$

$1.2: 30^{-5}$

25.700

$2,0=0$

950

$4 \geq 0$

200
1. 43

2.04

port

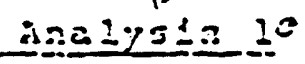

c. 1.2025 .

b C.E?इ

c $0.0=7 \%$.

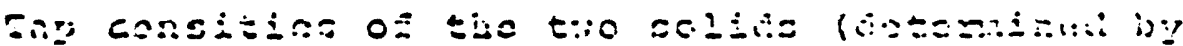

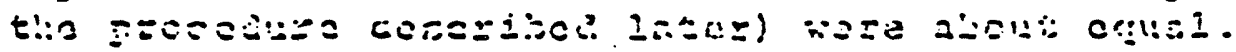

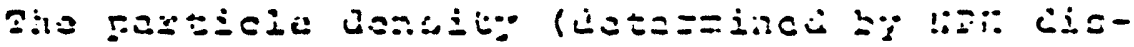

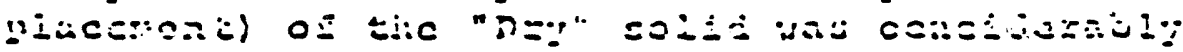

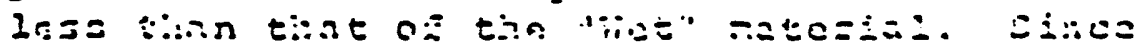

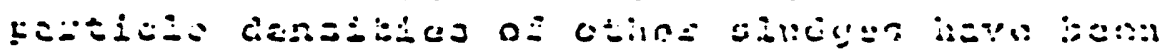

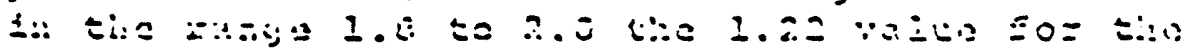

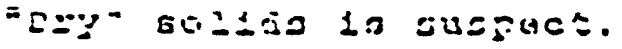




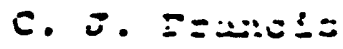

c. $\because \therefore$. …1 $1:: !=$

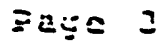

Jะก::ะ:! 12, 12:

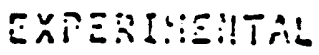

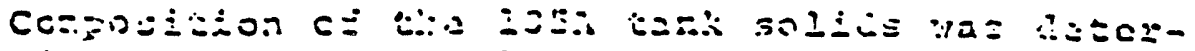

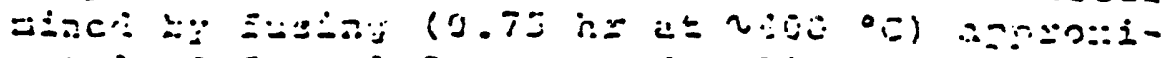

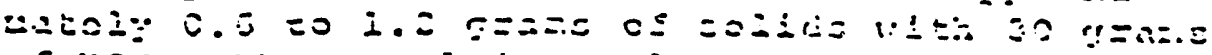
of !:0.: 6.

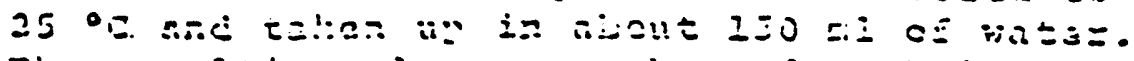

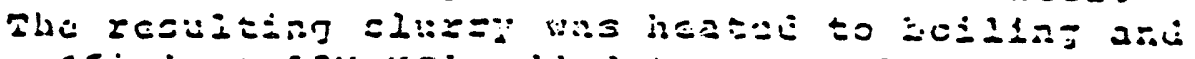

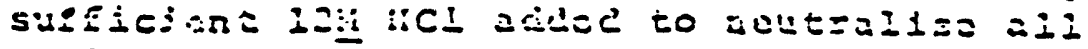
resiclual :0ii ano

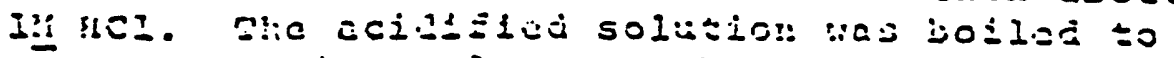

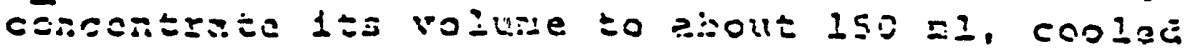

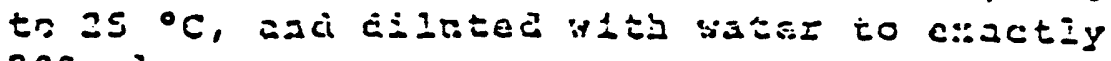
2005.

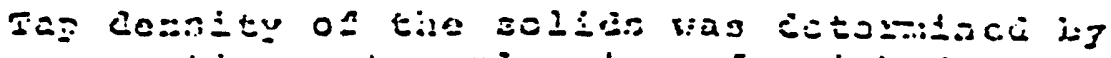

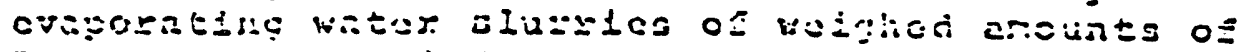
" $A=y^{\mu}$ ar: a

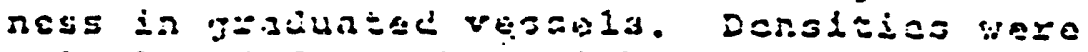

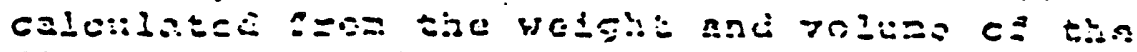

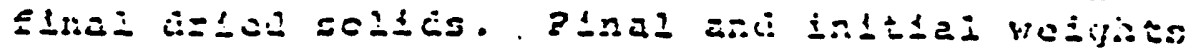

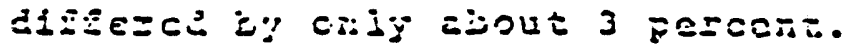

in: : 1

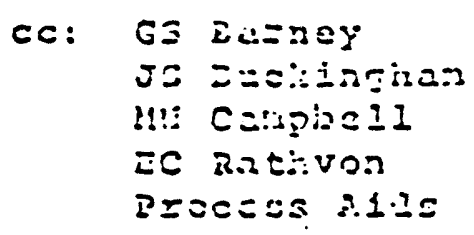


WHC-EP-0410

This page intentionally left blank.

APP B-4 
WHC-EP-0410

APPENDIX C

TANK FARM 241-A STATUS REPORT 
WHC-EP-0410

This page intentionally left blank.

APP $C-i j$ 
WHC-EP-0410

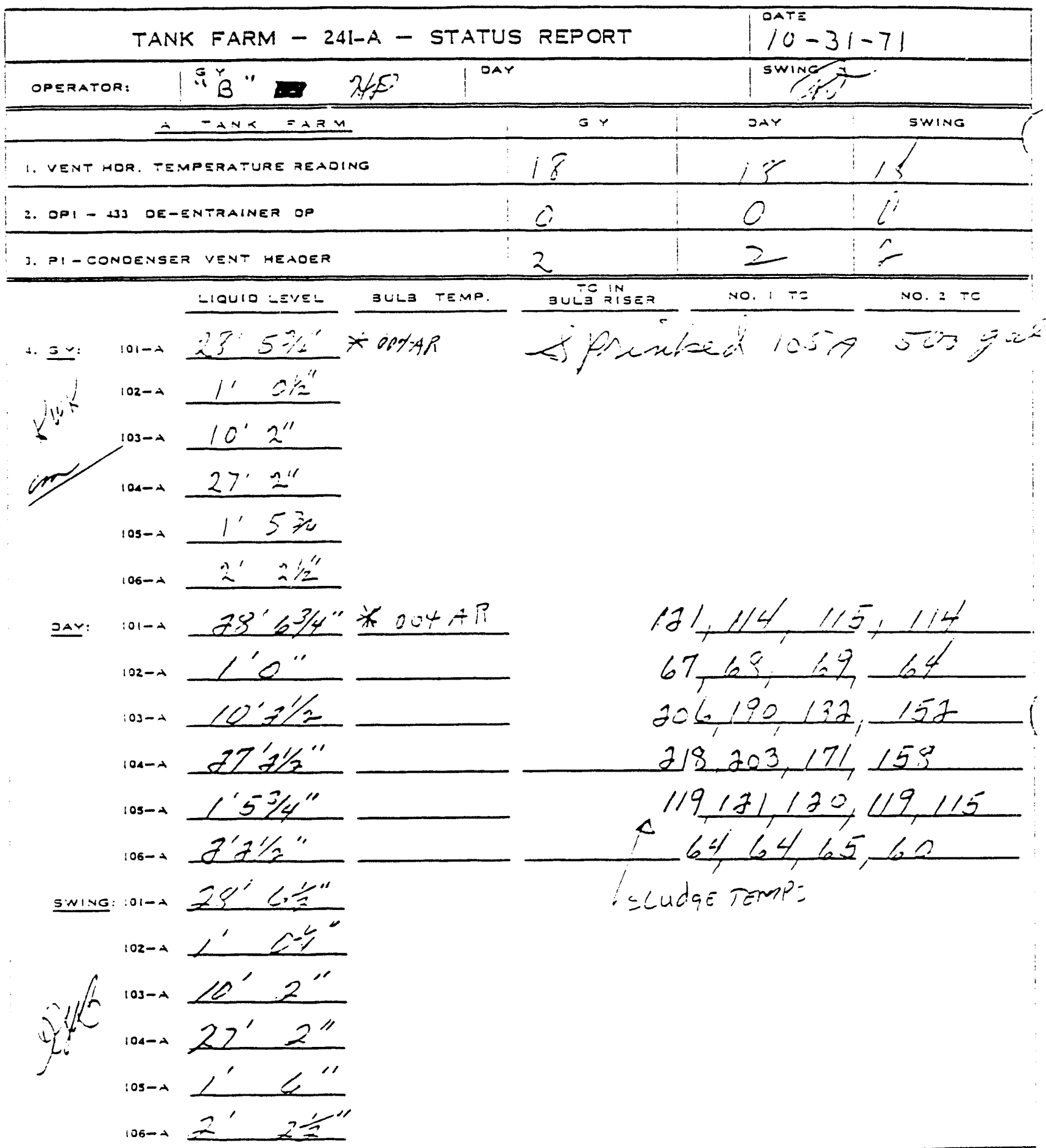

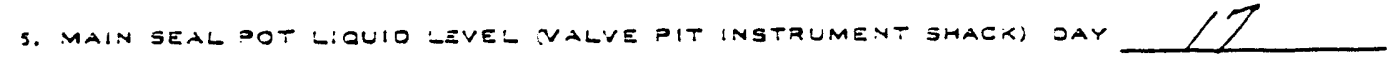

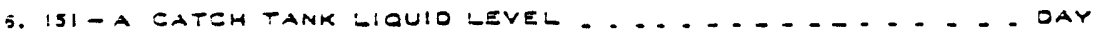

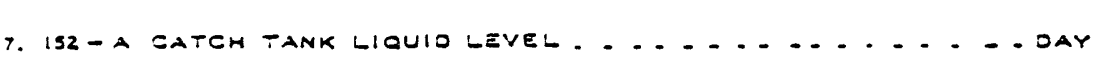

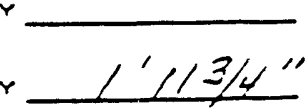

- 3. GONFIRM -HAT ALL A-FARM GIRCULATORS

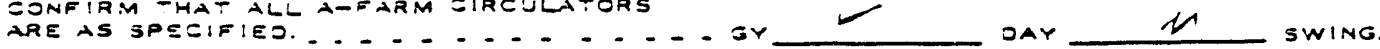

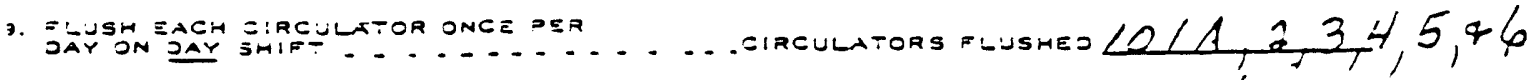
201-A 
WHC-EP-0410

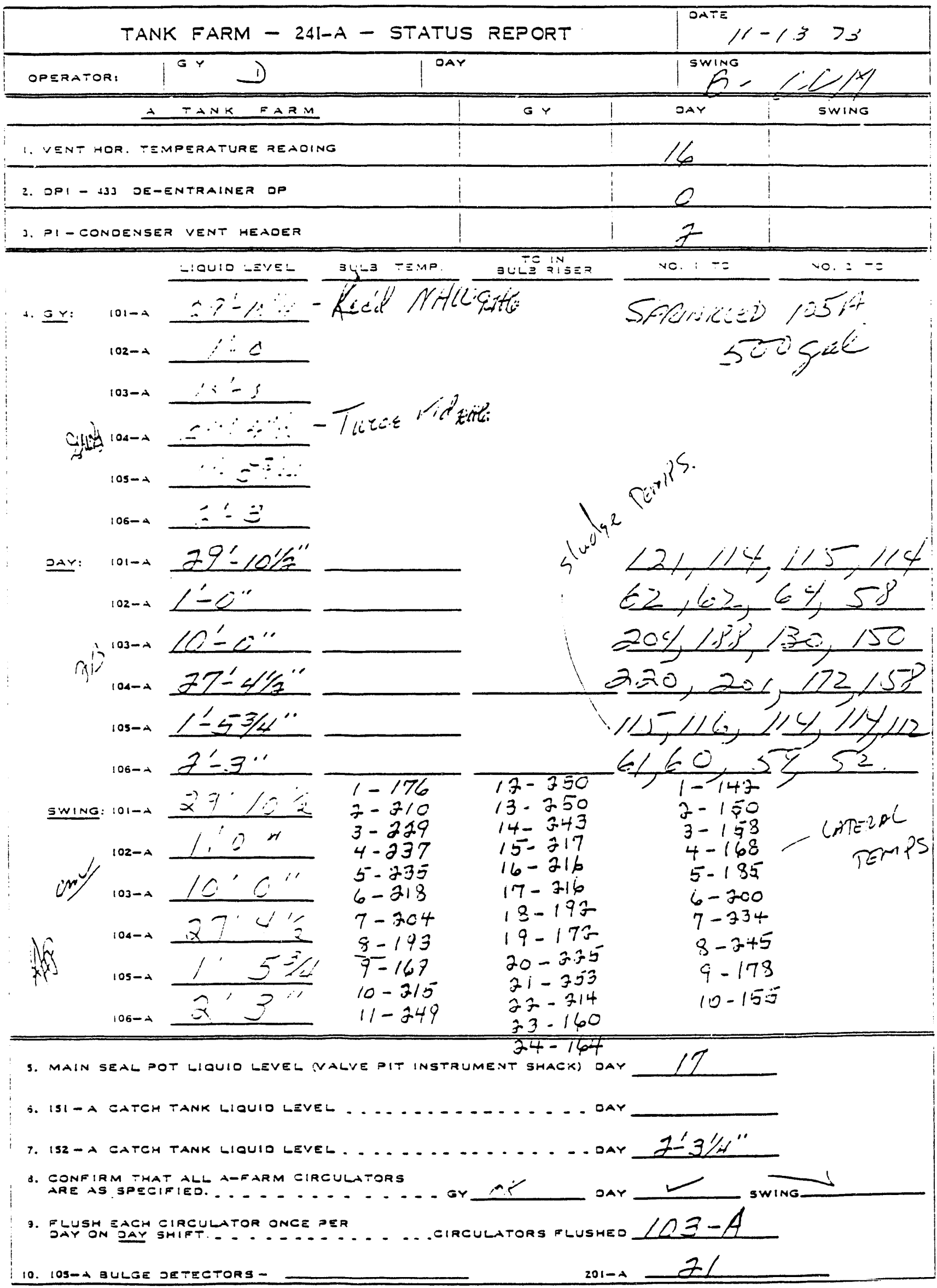

or -aenn-non is-ati................... 
WHC-EP-0410

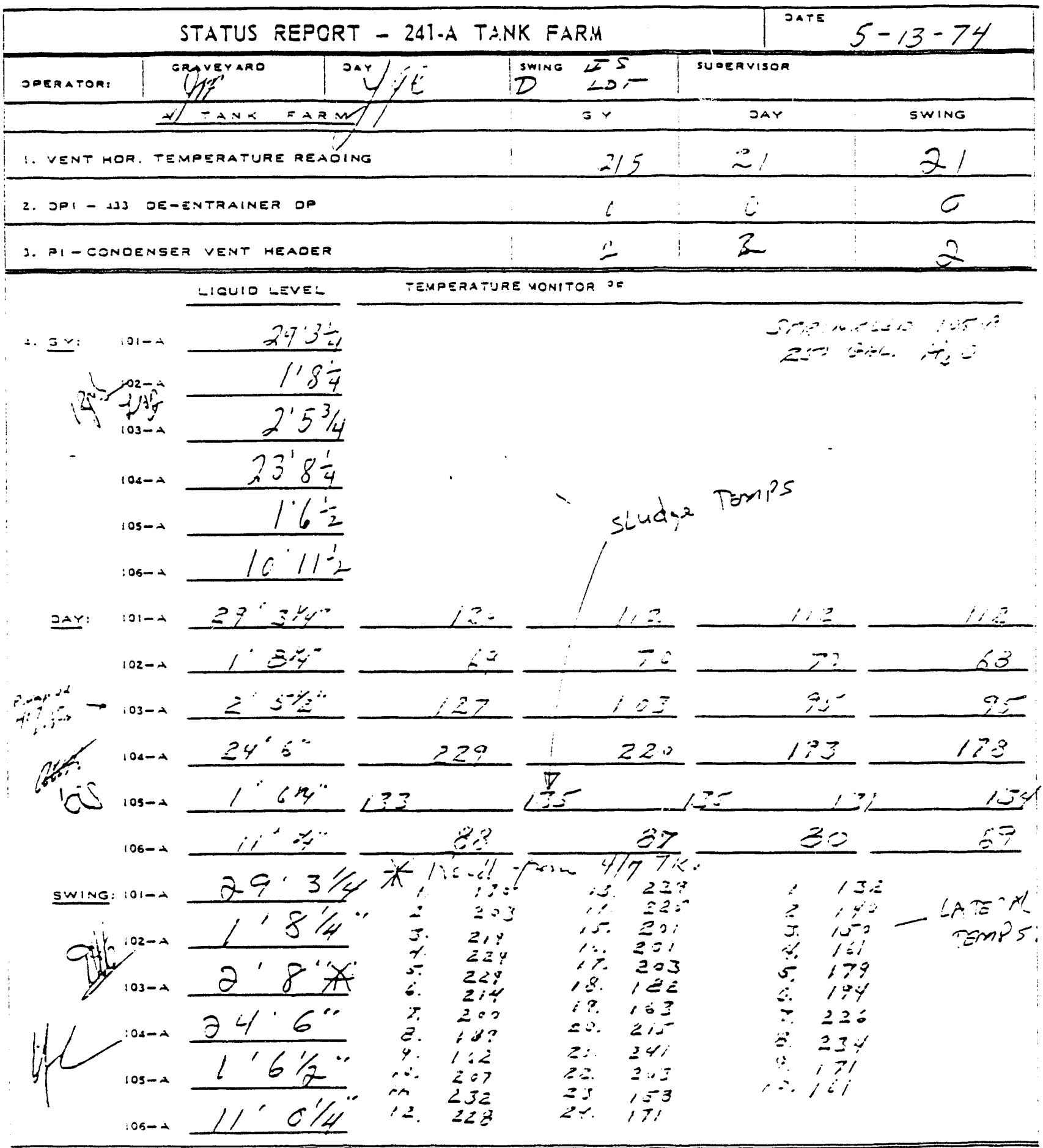

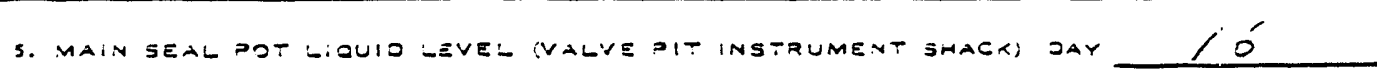

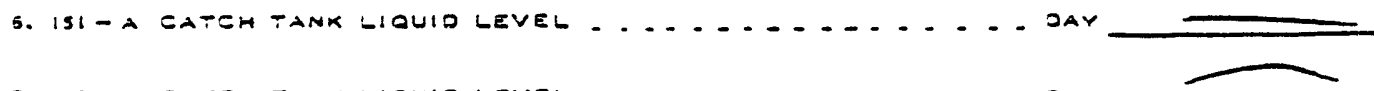

7. 132 - A EATCH TANK LIOUID LEVEL....................... JAY

3. CONFIRM THAT ALL A-PARM CIRCULATORS

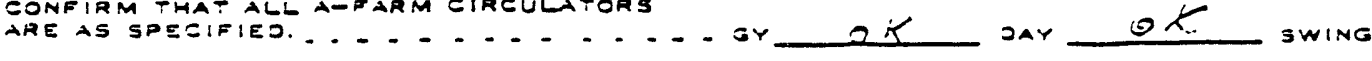

3. FUUSH EACH GIRCULATOR ONCE PER

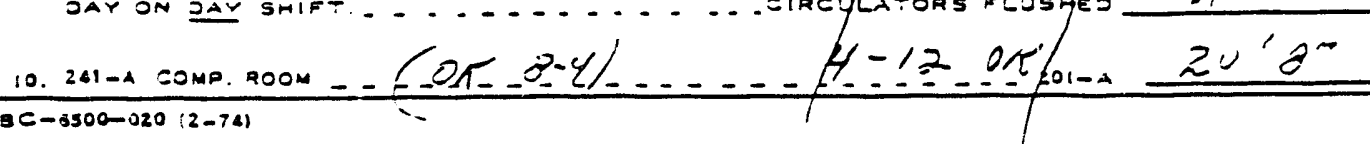
BC- $5500-020(2-74)$ - 
WHC-EP-0410

This page intentionally left blank.

APP $C-4$ 
WHC-EP-0410

APPENDIX D

RESULTS COMPARISON WITH DRAFT EBASCO ENVIRONMENTAL STUDY 
WHC-EP-0410

This page intentionally left blank.

APP $D-i i$ 


\section{RESULTS COMPARISON WITH DRAFT EBASCO ENVIRONMENTAL STUDY}

In a parallel effort with this report, Ebasco Environmental completed an engineering study "Draft Tank 241-A-105 Leak Assessment" (May 24, 1991), which estimates that approximately 610,000 gallons of cooling water were added to this tank and concludes that there was sufficient heat generated in the tank to evaporate "most, and perhaps nearly all of this water." The report, WHC-EP-0410, calculates the amount of water evaporated to be between 378,000 and 410,000 gallons. This appendix examines the Ebasco report and identifies the assumptions that produces the difference in calculated water evaporated.

The calculational approach of the Ebasco document was to use historical operating records and existing documentation to calculate a heat balance around the tank. The Ebasco approach calculates a total heat balance around the tank as shown in Equation 1.

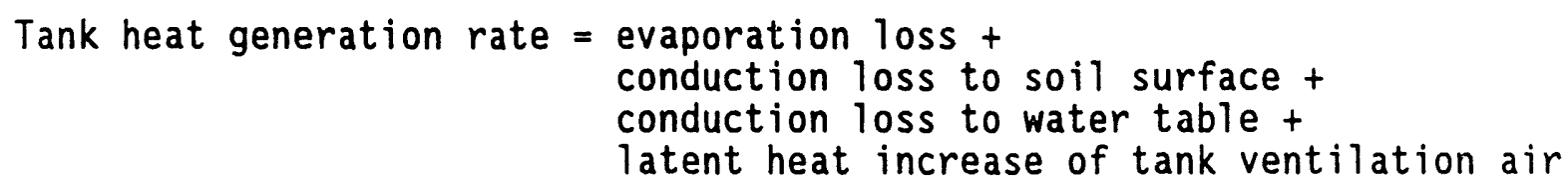

A value for each of these terms was calculated based upon a review of historical information.

An accurate value of the tank heat generation rate must be determined because it affects every term in Equation 1. The Ebasco study examines three sludge samples taken in 1972 and a third sample taken in 1965. The heat generation rates of the samples taken in 1972 varied by a factor of 3.6 . The heat generation rate of the sample taken in 1965 fell between two of the 1972 samples and was chosen as the assumed value. This volumetric generation rate was then multiplied by an estimated sludge volume to get a calculated tank heat conteni.

As seen by the variability of the 1972 analyses, the volumetric heat generation rate is not known to a high degree of accuracy. Estimates of the total sludge volume are also questionable. Multiplication of these two numbers can produce cumulative tank heat generation errors of a very high magnitude. The Ebasco study used this heat generation as the basis for its calculations. Instead WHC-EP-0410 used a heat transfer model and compared calculated model temperatures with measured tank temperatures and adjusted the heat generation rate until the model temperatures matched the measured temperatures. It is believed that these measured tank temperatures are the most accurate information that exists which can be used to estimate the actual tank heat generation rate.

The Ebasco document assumes a constant conductive heat loss of $2,140 \mathrm{Btu} / \mathrm{hr}$ to the water table and $6,960 \mathrm{Btu} / \mathrm{hr}$ to the soil surface. Actual values will be a function of the tank heat content. The greater the total heat content, the larger the conductive losses will be. Based upon a total tank heat content of $75,000 \mathrm{Btu} / \mathrm{hr}$, WHC-EP-0410 calculates conductive losses to the water table as 2,400 Btu/hr and conductive losses to the soil surface as $13,400 \mathrm{Btu} / \mathrm{hr}$. The value for the heat conducted to the water table is close to the value in the Ebasco document, but soil surface heat loss is twice as high as their assumption. Over the 9 year period in question, this amounts 
to almost 61,000 gallons less water evaporated or approximately $10 \%$ of the total amount of water added as tabulated in the Ebasco document.

The major difference between the Ebasco study and this document appears to be the assumed tank heat generation rate as shown in Table 1 .

Table 1. Total Heat Generation Rate

\begin{tabular}{|c|c|c|}
\hline \multirow{2}{*}{ Year } & Ebasco document & WHC-EP-0410 \\
\hline & \multicolumn{2}{|c|}{$\ldots-\cdots$ Btu/hr $\ldots$} \\
\hline 1971 & 102,600 & 81,330 \\
\hline 1972 & 94,900 & 78,328 \\
\hline 1973 & 90,200 & 75,383 \\
\hline 1974 & 86,900 & 72,507 \\
\hline 1975 & 84,300 & 69,718 \\
\hline 1576 & 82,000 & 66,989 \\
\hline 1977 & 79,900 & 64,323 \\
\hline 1978 & 77,900 & 53,596 \\
\hline 1979 & 75,900 & 59,183 \\
\hline
\end{tabular}

Assuming the difference between the two heat generation rates in Table 1 all went to evaporation of water and based upon an enthalpy change of $1,150.4 \mathrm{Btu} / 1 \mathrm{~b}$ for the evaporation of water, the extra heat assumed by the Ebasco document will evaporate an additional 130,673 gallons of water. Adding this number to the 410,000 gallons reported in this document gives a t,tal of 540,673 gallons. This value can be directly compared to the Ebasco number by subtracting the 61,000 gallons as noted previously from the 610,000 gallons number to give 549,000 gallons. This value compares very favorably with the 540,673 gallons shown above.

In conclusion, the Ebasco document and WHC-EP-0410 used two different engineering approaches: the Ebasco approach predicting 610,000 gallons evaporated and the WHC-EP-0410 approach predicting 410,000 gallons evaporated. Based upon the magnitude of possible errors in engineering assumptions, these numbers are the same. As discussed above, the difference in the amount of water evaporated can be attributed to the difference in the assumed heat generation rate. It is believed that the evaporation calculations in WHC-EP-0410 are closer to actual rates because temperatures in the model were benchmarked againsic ac: 1 measured tank temperatures and found to give close temperature agreement. 
WHC-EP-0410

DISTRIBUTION

Number of Copies

Onsite

11

U.S. Department of Energy-

Richland Operations office

G. J. Bracken

R4-04

P. Hamric

A7 -32

R. D. Hildebrand

A5 -55

R. E. Gerton

A4-02

J. Newson (5)

W. A. Rutherford

R4-04

Public Reading Room

A4-02

Al -65

1

Pacific Northwest Laboratory

B. Johnson

$\mathrm{K} 1-78$

33

Westingtiouse Hanford Company

G. K. Allen (3)

HO-34

D. V. Arbogast

L6-86

M. L. Bell

R. V. Berg

H4-23

D. C. Board

L6-29

E. J. Campbell

S1 -57

J. I. Dearning

B3-30

C. Defigh-Price

H5-58

J. L. Deichman

H4-23

G. T. Dukel ow

$\mathrm{H} 4-23$

D. J. Grean

R2-97

C. S. Haller

S5 -75

H. Harmon

R1-51

M. N. Islam

R2-52

W. L. Knecht

A. J. Knepp

S. Marchetti

R. L. Miller

D. M. Ogden

j. G. Propson

T. E. Rainey

R. E. Raymond

R3-08

HO-33

H4 -56

R2-50

$\mathrm{HO}-34$

HO- 34

R2-18

RI -49

RI -80

L. E. Thomas

R3-08

J. D. Thomson

RI-30

R. K. Weity

RI-80

Central Filos

L8-04

CDMC

H4-22

Information Release Administration (3)

L8-04

Tank Farm Information Center

R2-95 

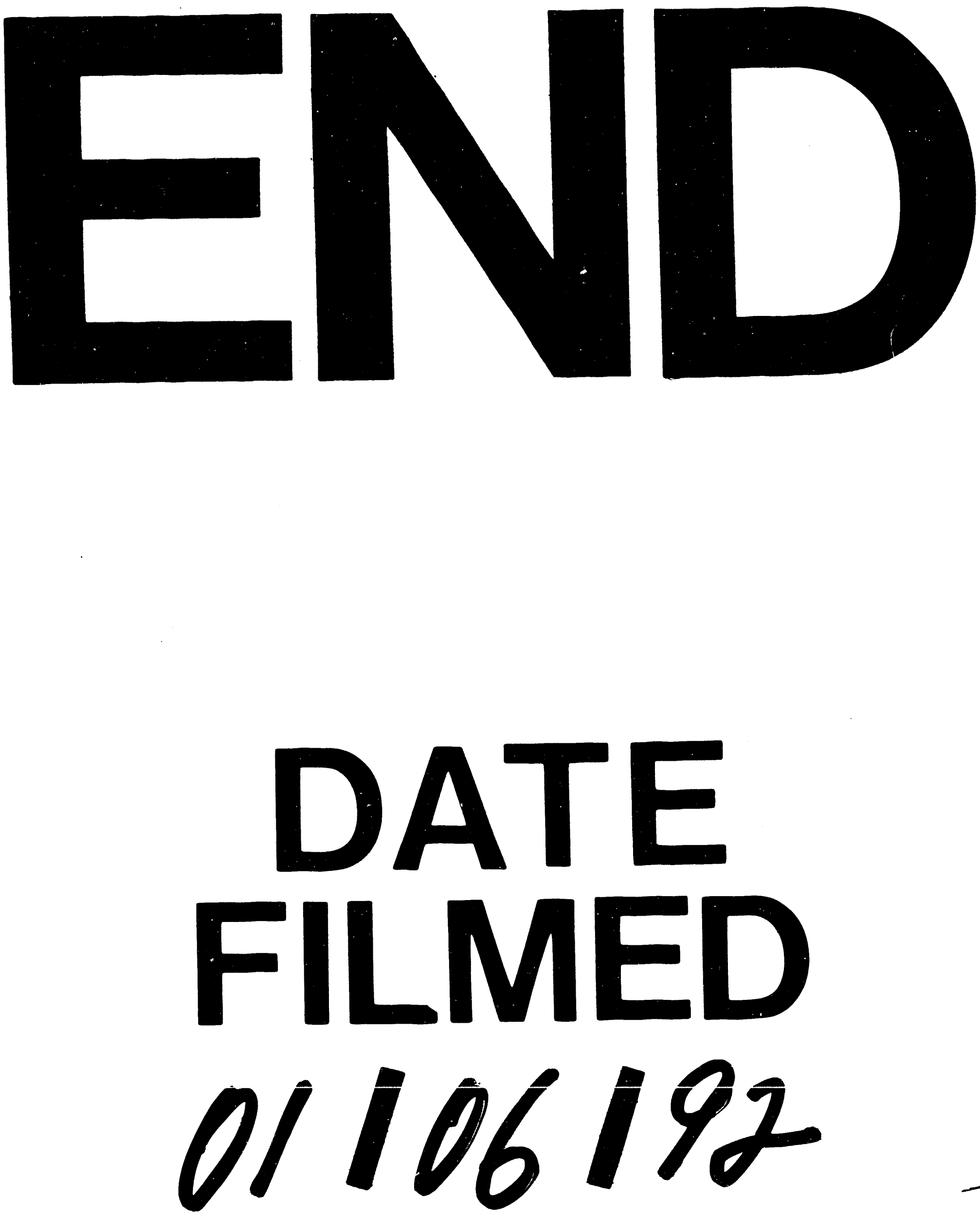


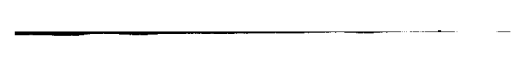

